\title{
THE FISCAL EFFECTS OF IMMIGRATION TO THE UK*
}

\author{
Christian Dustmann and Tommaso Frattini
}

\begin{abstract}
We investigate the fiscal impact of immigration on the UK economy, with a focus on the period since 1995. Our findings indicate that, when considering the resident immigrant population in each year from 1995 to 2011, immigrants from the European Economic Area (EEA) have made a positive fiscal contribution, even during periods when the UK was running budget deficits, while Non-EEA immigrants, not dissimilar to natives, have made a negative contribution. For immigrants that arrived since 2000, contributions have been positive throughout, and particularly so for immigrants from EEA countries. Notable is the strong positive contribution made by immigrants from countries that joined the EU in 2004.
\end{abstract}

Much of the economic literature over the last two decades, responding to concerns about the impact of immigration on labour markets, has focussed on immigration's possible impact on native workers' wages and their employment (Card, 1990, 2001; Altonji and Card, 1991; Borjas, 2003; Dustmann et al., 2005, 2013; Manacorda et al., 2012; Ottaviano and Peri, 2012). A possibly even larger concern in the public debate on migration, however, is whether immigrants contribute their fair share to the tax and welfare systems. Indeed, in their analysis of attitudinal data, Dustmann and Preston (2007) provide strong evidence that this concern is more important for individuals' assessments of immigration policies than concerns about wages or employment. Such worries about the negative fiscal effects of immigration are also reflected in survey responses. For instance, when asked in the 2008 European Social Survey whether immigrants receive more or less in social benefits than they contribute in taxes, $44 \%$ of European citizens responded that immigrants receive more than they contribute, with only $15 \%$ believing that they receive less. In this same survey, only $8 \%$ of European citizens agreed that immigrants should have the right to receive social benefits and services immediately upon arrival in the host country, 38\% favoured granting this right only after immigrants have worked and paid taxes for at least one year, $37 \%$ supported it only after they have acquired citizenship of the host country and more than $8 \%$ believed that immigrants should never obtain the same rights as natives. There is also solid evidence that policy makers react to such common beliefs and public concern about immigration by restricting welfare access (see also Boeri, 2010). For example, the labour government under Tony Blair opened UK labour markets to the new Central and Eastern European community member states in 2004 but restricted access to the welfare system, ${ }^{1}$ and similar restrictions were discussed as

* Corresponding author: Christian Dustmann, Department of Economics, University College London, Drayton House, 30 Gordon Street, London WC1H 0AX, UK. Email: c.dustmann@ucl.ac.uk

We are grateful to Bernt Bratsberg, Michael O'Connor, Ian Preston, Oddbjørn Raaum, Robert Rowthorn, Mervyn Stone, Frederic Vermeulen and Nigel Williams for comments and suggestions on earlier versions of this article.

${ }^{1}$ Citizens of new EU member states gained access to income-related benefits (income support, pension credit, jobseeker's allowance, housing benefit and council tax benefit) only after 12 months of continuous employment in the UK. 
part of the debate in the UK in regard to Bulgaria and Romania in 2014. It is thus surprising that there is so little research that provides substantive evidence on immigrants' fiscal contribution.

In this article, we study the fiscal impact of immigration to the UK, a country in which concerns about immigration seem frequently articulated. ${ }^{2}$ In doing so, we perform three types of analysis. First, based on survey information from the UK Labour Force Survey (LFS), we assess the probability of different immigrant groups receiving benefit payments or tax credits and living in socially provided housing. Second, we consider the total population of immigrants who resided in the UK in each year between 1995 and 2011, distinguishing between immigrants from countries that are not part of the European Economic Area (EEA) and immigrants from EEA countries, and then compute their net fiscal contribution in each of these years. Third, we perform the same analysis but for all immigrant cohorts who arrived in the UK since 2000 over the period between 2001 and 2011. ${ }^{3}$ For this analysis, we further break down immigrants into those who arrived from A10 countries and those who came from the rest of the EU. ${ }^{4}$ This latter is a decidedly meaningful distinction, given the current debates about free labour movement between the UK and other European countries and the shift in immigration from predominantly Commonwealth countries to European countries, particularly those in Eastern and Central Europe.

We compute the net fiscal contribution of different population groups by assigning individuals their share of cost for each item of government expenditure and identifying their contribution to each source of government revenues. This procedure allows us to provide estimates for each year on both the overall expenditure on the respective immigrant populations and the revenues they have produced in comparison to native born workers. Thus, although our approach is 'static' in the sense that we do not compute the hypothetical life cycle contributions for each immigrant at one point in time (see Preston (2014) on the advantages and disadvantages of such an approach), it is also 'dynamic' in that we provide a clean picture of the UK immigrant populations' net contribution to the tax and benefit system over a longer period.

Our analysis not only builds on but goes substantially beyond previous studies of the fiscal effects of immigration for the UK, which are more limited in scope. ${ }^{5}$ Several such studies, for example, focus on all immigrants irrespective of migration seniority and address only specific years (Gott and Johnston, 2002; Sriskandarajah et al., 2005;

\footnotetext{
2 According to the Autumn 2012 Eurobarometer, 24\% of UK citizens, as opposed to an average $8 \%$ of EU residents, believe that immigration represents one of the two most important issues facing the country. (http://ec.europa.eu/public_opinion/archives/eb/eb78/eb78_publ_en.pdf).

3 It should be noted that these two groups are different. Analysis of the first group provides a simple 'snapshot' of a population at different points in time but depends on the demographic composition of the immigrant population at respective measurement points, which in turn depends on historical migration pattern. Analysis of the second group, in contrast, allows us to make statements about the fiscal contributions of complete arrival cohorts observed from entry to the UK onwards.

${ }^{4}$ The A10 countries are Bulgaria, Czech Republic, Estonia, Hungary, Latvia, Lithuania, Poland, Slovakia, Slovenia and Romania.

${ }^{5}$ Our analysis is confined to the population reported in the UK Labour Force Survey, which may include some illegal immigrants, but is likely to under-represent that group. Illegal immigrants - while likely to work in the black economy and therefore not pay taxes - are also not entitled to benefits or transfers.
} 
Rowthorn, 2008). Likewise, some analyses concentrate only on the difference between taxes paid directly by immigrants, including social security contributions and the social transfers they receive (Liebig and Mo, 2013), while others investigate only certain sub-populations, such as immigrants from the eight Central and Eastern European countries that joined the EU in May 2004 and came to be known collectively as A8 immigrants (Dustmann et al., 2010). ${ }^{6}$

Our main findings can be summarised as follows. We show that, over the period between 1995 and 2011, immigrants who resided in the UK in any of these years have been generally less likely than natives to receive state benefits or tax credits and also less likely to live in social housing as natives in the same region. Some differences do emerge, however, between immigrants from the EEA and those from outside Europe (non-EEA). The difference in transfer receipt between natives and recently arrived immigrant cohorts (i.e. those who arrived since 2000) is even larger. All groups of recently arrived immigrants are also less likely than natives in the same region to live in social housing, except for non-EU immigrants, who are equally likely.

Regarding the net fiscal impact of immigrants, we find for our baseline scenario, ${ }^{7}$ and considering the immigrant population that resided in the UK over the 1995-2011 period, that over a period during which the fiscal cost of natives cumulated to $£ 591$ billion, EEA immigrants contributed $10 \%$ more than natives (in relative terms), and non-EEA immigrant contributions were almost $9 \%$ lower. On the other hand, recent immigrants, i.e. those who came after 1999, have made positive fiscal contributions irrespective of origin. Between 2001 and 2011, the net fiscal contributions of recent A10 immigrants amounted to almost $£ 5$ billion, those of the other recently arrived European immigrants to $£ 15$ billion, and those of recent nonEuropean immigrants to a total of over $£ 5$ billion. Remarkably, over the same period, the natives' fiscal cost amounted to almost $£ 617$ billion.

Immigrants also provide savings to the taxpayer by bringing with them educational qualifications paid for by their countries of origin. Calculating the annuities for immigrants' effective education (i.e. the level of education corresponding to the educational requirement for their occupation), we find that between 1995 and 2011 European immigrants endowed the UK labour market with human capital that would have cost $£ 14$ billion if it were produced through the British education system. Likewise, over the same period, the annuities of non-European immigrants' education amounted to an implicit savings of more than $£ 35$ billion. Focusing on those immigrants who arrived between 2001 and 2011, such implicit savings to the UK taxpayers total about $£ 18$ billion. A substantial additional saving to the UK taxpayer is also created by immigrants' contributing to 'pure' public goods, about $£ 82$ billion between 1995 and 2011.

We perform extensive sensitivity analysis, which does not alter our main conclusions: immigration to the UK since 2000 has been of substantial net fiscal benefit, with

\footnotetext{
${ }^{6}$ See Barrett and McCarthy (2008) and Drinkwater and Robinson (2013) for related studies on the welfare participation of immigrants in the UK.

7 As explained below, this scenario allocates the contribution that the children of immigrants make to natives while apportioning the cost of their education to immigrants and assigns the average (rather than marginal) cost of all pure and congestible public goods to immigrants. It is, therefore, likely to underestimate immigrants' net fiscal contributions.
} 
immigrants contributing more than they have received in benefits and transfers. When we additionally consider the savings to the UK taxpayer from immigrants bringing their own educational qualifications whose costs are borne by other countries and contributing to financing fixed public services, these savings are even larger. European immigrants, particularly, both from the new accession countries and the rest of the European Union, make the most substantial contributions. Overall, therefore, our analysis draws a positive picture of immigration's fiscal effects on the UK. In particular, immigrants who arrived since 2000, especially those from EEA countries, have through their positive net fiscal contributions - helped to reduce the fiscal burden for native workers.

The remainder of the article unfolds as follows. Section 1 provides a detailed discussion of our conceptual framework, the assumptions made and our measures for the expenditures and revenues that underlie our analysis. Section 2 outlines our data, Section 3 provides a brief assessment of UK migration over the period studied, Section 4 reports our results and Section 5 presents our sensitivity analysis. Section 6 concludes the article.

\section{Conceptual Issues and Measurement}

\subsection{Conceptual Issues}

The assessment of the fiscal contribution of immigrants typically assigns to each individual his or her estimated tax contributions and the expenditures in benefit payments and public services received. Doing so accurately, however, requires detailed data on the various items of government revenues and expenditures, data that are not always available. It also requires that the researcher estimates the amount attributable to each individual or group of individuals for all items. This estimation exercise must necessarily rely on rich survey data on the population of interest, complemented by administrative data sources. In the next Section, therefore, we describe precisely how we compute these numbers and how we deal with incomplete information.

Even were there no deficiencies in the underlying data, several conceptual issues must be addressed, particularly in terms of how the contributions of, and expenditures on, immigrants should be allocated (Rowthorn (2008) and Preston (2014) for further discussion). For example, we must resolve how to allocate the cost of education, which in most countries is heavily subsidised. Particularly important is how the cost of immigrant children's education is allocated across populations, especially when immigrant fertility is higher than that of natives. A related question concerns the education that immigrants bring with them, the cost of which has been borne by the country of origin. It must also be determined how public goods should be allocated whose supply is 'fixed'; that is, goods whose provision does not increase with population growth. To address these issues, we take a very cautious approach in our baseline scenario in that the numbers presented below are likely to be underestimates of the overall net contributions that immigrants make to the tax and welfare system. 


\subsubsection{Second generation immigrants}

How, then, should one classify second-generation immigrants - i.e. the UK-born children of immigrants - in an analysis of immigrants' fiscal contributions? In most education systems, the heavy subsidisation of primary and secondary education is effected through the tax contributions of the working population. Hence, financing the education of the next generation is part of an intergenerational contract, one in which the working population finances the education of the next generation, which will in turn finance the subsequent generation and - depending on the pension system - the current working populations' retirement costs (Rangel, 2003; Boldrin and Montes, 2005). Hence, the children of immigrants, if they remain in the receiving country, will contribute to both the education of the next generation and the pensions of the current working population. In that sense, they will pay off the investments made in their educational formation. Thus, even though immigrant children consume public services while at school, they will contribute to the next generation by paying taxes later in their lives. In fact, because British-born descendants of immigrants tend to perform better in public schools and acquire more education, ${ }^{8}$ they may make a relatively higher net fiscal contribution than natives.

Empirically, however, serious data limitations prevent us from identifying adult second-generation immigrants. The LFS has no information on parents' country of birth for individuals who live outside their parents' household. Hence, secondgeneration immigrants can only be identified while they are children (i.e. while they are living in their parents' households), which is also the age range at which they consume educational services. When grown up, working and paying taxes, and making fiscal contributions, they are not identifiable in the survey data available to us. In our analysis, therefore, we consider immigrants' children under the age of 16 as immigrants regardless of birth country but classify as natives everyone who is at least 16 and UK born, regardless of parents' birthplace. ${ }^{9}$ This choice, it should be noted, suggests that we are neglecting the contribution that these the children of immigrants will make when they enter the labour market. Likewise, we are neglecting the costs of educating the immigrants themselves, which - other than the cost of educating the native born workforce - has been borne not by British taxpayers but by taxpayers in the origin country. ${ }^{10}$ Thus, while assigning to immigrants the cost of educating their UK-born children, we are unable to assign to them the benefits that their children will bring after leaving the education system and entering the labour market. In this sense, all the results presented below are underestimates of immigrants' net fiscal contribution.

\footnotetext{
${ }^{8}$ See Dustmann et al. (2011) for evidence of the descendants of minority immigrants, and Dustmann and Theodoropoulos (2010) for the overall educational attainments of British-born descendants of minority immigrants.

9 Since the LFS has no direct information on parents' country of birth, we can infer it only for individuals who live in the same household as their parents. For this reason, we have limited our attention to secondgeneration immigrants under the age of 16 , who presumably do not live alone. We have also dropped from our sample all individuals under 16 who do not live with their parents (e.g. those living with their grandparents or other adults).

${ }^{10}$ We assess the magnitude of these savings in additional analysis below. 


\subsubsection{Average population versus arrival cohorts}

Below, we provide two sets of computations: the estimated fiscal contribution of the population of immigrants resident in the UK over the 1995-2011 period and the estimated fiscal contribution for 2001-11 of all immigrants who arrived after 2000. It should be noted that these two sets of estimates have different interpretations and thus are not comparable. The aim of the second set is straightforward: it answers the welldefined question 'What is the net fiscal contribution of immigrants who arrived in the UK since 2000?', thereby providing a clean description of individuals from the start of residency onwards. The first set, on the other hand, focuses on all immigrants who reside in the UK in each year between 1995 and 2011 regardless of arrival date and thus depends on past immigration dynamics, which in turn determine the demographic composition of the immigrant population at any point in time. To illustrate, given a hypothetical cohort of immigrants who arrived in 1950 and are observed in 1995, the 1950 arrival cohort has been in the UK for 45 years. The net fiscal contribution of that cohort for the years after 1995, therefore, is not informative about its overall net fiscal contribution because we do not observe its net fiscal contributions for the first 45 years after arrival. In fact, as this cohort is now older, it is likely to have high rates of welfare dependency and low labour force participation that do not reflect its overall contributions since arrival. Moreover, a substantial fraction of the immigrants who originally came in 1950 may have returned to their home countries by 1995 , after spending their most productive years in the UK. ${ }^{11}$ Hence, as this example shows, the net fiscal contribution of immigrant populations at a particular point in time varies according to demographic composition, which in turn depends on historic arrival intensities and return migration pattern. Therefore, although we report these figures for completeness, such figures are difficult to interpret, which is one rationale for focusing our discussion on arrival cohorts since 2000.

\subsubsection{Net fiscal contributions and the deficit}

As detailed below, the approach followed in this article allocates all revenues and all expenditures for each fiscal year to different populations. First, the sum of all revenues and expenditures approximates the deficit that the UK is running in a particular year. ${ }^{12}$ Thus, for an average individual, the net fiscal contribution will be negative in year $t$ if the UK runs a deficit in that year and positive if it runs a surplus, even when the individual's behaviour remains the same in both situations. As a result, the absolute net contributions of different populations may not be a meaningful measure of their fiscal contribution because these figures depend on the magnitude of the deficit. What is more insightful is their relative contribution in comparison to other population groups, especially as this comparison somewhat 'eliminates' the common deficit effect as far as it affects different groups in the same way. We, therefore, focus much of our

\footnotetext{
11 Dustmann and Weiss (2007) show that return migration is substantial in the UK. Of all the immigrants who entered the UK between 1992 and 2002 and stayed for at least one year, over $40 \%$ returned within the first five years after migration.

12 Our calculations do not consider the fraction of capital and corporate taxation that is probably paid from abroad (see subsection 1.2.3 for more detail).
} 
subsequent discussion on the differences in the net fiscal contributions of different immigrant groups to natives, our reference population.

\subsubsection{Public goods}

What, then, is the cost of providing public goods to immigrants? Answering this question is critical because public goods and services represent a substantial part of government expenditures (about one-third of total government expenditures in the UK, with a slight decrease from over $35 \%$ in 1995 to $28 \%$ in 2011). Thus, the choice of the apportioning coefficient for public goods plays an important role in determining the overall result of any analysis of the type reported here. In our calculations, we distinguish between two types of public goods and services: 'pure' and 'congestible'. ${ }^{13}$ 'Pure' public goods and services are not rival in consumption and the marginal cost of providing them to immigrants is likely to be zero. For example, the expenditure for defence or for running executive and legislative organs is largely independent of population size. 'Congestible' public goods and services are - at least to some extent rival in consumption, so the marginal cost of providing them is unknown, although probably smaller than the average cost and positive. For example, the cost of fireprotection services, waste management and water supply may indeed increase with the size of the resident population.

Arguably, therefore, pure public goods can be provided in the same amount and at the same cost regardless of immigration level, in which case, the marginal cost of providing them to an immigrant would be zero. Hence, if it is the average cost of that public good that is assigned to the immigrant, immigration simply allows the cost to be shared among a larger number of individuals and thus represents a form of implicit saving for natives. Conversely, immigration can be expected to increase the expenditure for congestible public goods and services, although probably less than proportionately (in other words, the marginal cost is likely to be smaller than the average cost) ${ }^{14}$

Obviously, the ideal would be to measure the marginal cost of providing each public good and assign it to every new immigrant. Unfortunately, however, no data are available on the marginal cost of public good provisions, so all we know is the average cost (the ratio of total expenditure for the good to the total population). In addition, although the marginal cost of public goods provision is, therefore, likely to be lower than its average cost, in our analysis, in most cases, we assign to immigrants the average cost of publicly provided goods and services, thereby probably overestimating the fiscal cost component of these items for immigrants.

In our 'average effect scenario', the marginal cost of providing public goods to immigrants is assumed to equal their average cost. We also, however, compute a second 'marginal effect scenario' in which we assume that the marginal cost of providing 'pure' public goods to immigrants is zero and apportion all government expenditures for 'pure' public goods to natives only. ${ }^{15}$ The difference between the amount of public

\footnotetext{
13 See the Appendix Table A3 for a detailed list of all goods and services in each category.

${ }^{14}$ We recognise that the marginal cost of provision could also be higher than the average cost in some instances because of congestion; however, no evidence exists that this is the generally the case (Rowthorn, 2014).

15 Rowthorn (2014) believes that the 'marginal effect scenario' in which pure public goods are assigned to immigrants at zero marginal costs is preferable.
} 
expenditure apportioned to natives in the first and second scenario allows us to assess the implicit savings that immigration generates for natives through sharing of the cost burden of pure public goods across a larger population. This potentially important aspect of immigration's fiscal contribution has to date been largely neglected.

A related question is what marginal contribution immigrants make to government revenues through interests and dividends and to government's gross operating surplus and rents. In our analysis, we apply to these sources of government revenues the same apportioning criteria as for 'pure' public goods. Hence, when assuming that immigrants bear the average cost of public goods, we also apportion to them the average revenue from interests and dividends and from gross operating surplus. Conversely, when we allocate the cost for 'pure' public goods to natives only, we attribute all revenues from interest and dividends and from gross operating surplus to natives only.

\subsection{Estimation and Measurement}

\subsubsection{Benefits, transfers and social housing}

In the first part of our analysis, we assess the degree to which immigrants draw on benefits and tax credits or live in social housing in comparison to natives. ${ }^{16}$ This allows a first assessment as to whether immigrants in the UK make disproportionate use of welfare services. Moreover, unlike in the subsequent analysis on the overall fiscal cost of immigration, we are able to study differences in welfare use between immigrants and natives overall, as well as immigrants and natives who are similar in their age-gender profiles, thus addressing both factual and counterfactual scenarios. To do so, we use responses to questions in the LFS that address two interrelated issues: the first is whether individuals claim any type of benefits or tax credits, including unemployment related benefits, National Insurance credits, income support, sickness or disability benefits, state pension, family-related benefits, child benefits (since 2001), housing/ council tax (GB) or rent/rate rebate (NI) and/or tax credits. The second is the type of landlord from whom tenants are renting. Based on this latter, we define 'living in social housing' as all individuals who rent their accommodation from local authorities or housing associations. ${ }^{17}$

We are thus able to construct two indicator variables identifying

(i) benefits/tax credits claimants; and

(ii) those living in social housing.

We then estimate simple probability models, based on the linear index function

$$
y_{i t}^{*}=\alpha+\beta I_{i t}+\mathbf{X}_{i t} \gamma+T_{t}+u_{i t}
$$

\footnotetext{
16 To claim most means-tested benefits, such as income support, housing and council tax benefits, immigrants have to pass the so-called habitual residence test (HRT). In particular, immigrants must have a right to reside in the UK in order to claim benefits. Immigrants who have the right to reside can also claim child benefits and child tax credits. The right to reside depends on nationality and immigration status. EEA nationals are automatically given right to reside for three months upon entry in the UK but this does not qualify them for HRT unless they take up work in the UK.

17 Housing associations are non-profit organisations that typically receive public funding and whose functioning is regulated by the state.
} 
where the probability that an individual receives any form of transfer or lives in social housing is given by $\operatorname{Prob}\left(y_{i t}=1\right)=\operatorname{Prob}\left(y_{i t}^{*}>0\right)$. Assuming that $u_{i t} \sim \mathrm{N}(0,1)$ results in the probit model. The parameter of interest here is $\beta$, which measures the association between immigrant status $I$ and welfare and transfer receipt or living in social housing. We always condition on a set of year-quarter interaction dummies $T_{t}$, so the estimate of $\partial \operatorname{Prob}\left(y_{i t}=1 \mid T_{t}\right) / \partial I_{i t}$ represents the weighted averaged difference in the probability of receiving benefits or living in social housing between immigrants and natives, conditioned on fluctuations in welfare receipt over time that affect immigrants and natives alike. We evaluate this difference at the mean value of the time dummies for natives.

However, even though $\beta$ is the parameter of interest for measuring the average difference in the probability of welfare receipt between immigrants and natives over a particular period, it may also be interesting to compare immigrants and natives who are identical in some observed characteristics, such as age, gender or residential location. To address this second aspect, we also estimate models that condition on the vector $\mathbf{X}$, which includes dummies for five-year age groups, interaction of the age dummies with gender dummies (in the analysis of benefits receipt) and region of residence (in the analysis of social housing). The marginal effects we report are evaluated at the average values of $T_{t}$ and of the characteristics vector $\mathbf{X}$ of natives. In the study of welfare dependency, the unit of analysis $i$ is the individual; in the analysis of social housing, it is the household (defined as a single person or group of people living at the same address who report that address as their only or main home). Using this latter as the analytic unit allows us to assess the number of residential units occupied by immigrants and fully accounts for differences in average household size between natives and immigrants.

\subsubsection{Fiscal cost and benefit}

To compute estimates on immigrants' net fiscal contributions, we adopt an approach similar to that used by Dustmann et al. (2010) and construct quantitative measures of immigrants' cost and tax receipts. Instead of focusing only on one group of immigrants, however, we adapt the methodology to examine the net fiscal contributions of immigrants from two areas of origin (EEA and non-EEA). We perform analyses both for the resident immigrant population in the UK in each year between 1995 and 2011 and for recently arrived cohorts, defined as all immigrants who arrived since 2000 (see subsection 1.1.2). We further break down this second group into immigrants from one of the 10 Central and Eastern European countries that joined the EU in 2004 or in 2007 (A10 countries), immigrants from the other EEA countries and non-EEA immigrants.

Because in every year $t$, the government surplus or deficit $\left(G S U R_{t}\right)$ amounts to the difference between receipts $\left(R E V_{t}\right)$ and expenditures $\left(E X P_{t}\right)$, total receipts can be decomposed into the revenue from each tax and duty levied by the government, plus interest and dividends and gross operating surplus and rents. We designate $r e v_{i t}$ as the amount received by the government from the revenue source $i$ in year $t$, and $N_{R}$ as the number of revenue sources. Similarly, total expenditures in every year can be decomposed into expenditure for $N_{E}$ different services, with exp $p_{j t}$ denoting the expenditure for service $j$ in year $t$. The total government surplus can thus be written as 


$$
G S U R_{t}=R E V_{t}-E X P_{t}=\sum_{i=1}^{N_{R}} r e v_{i t}-\sum_{j=1}^{N_{E}} \exp _{j t} .
$$

We then further decompose each revenue and expenditure item $r e v_{i t}$ and $\exp _{j t}$ into the amount paid or received by natives versus immigrants (distinguishing between natives and immigrants from different origins as explained above) ${ }^{18}$ indexed by $k=1,2, \ldots, K$ and rewrite (2) as

$$
G S U R_{t}=\sum_{k=1}^{K}\left(\sum_{i=1}^{N_{R}} \alpha_{i t}^{k} r e v_{i t}-\sum_{j=1}^{N_{E}} \beta_{j t}^{k} \exp _{j t}\right)=\sum_{k=1}^{K}\left(R E V_{t}^{k}-E X P_{t}^{k}\right)=\sum_{k=1}^{K} G S U R_{t}^{k}
$$

where $\alpha_{i t}^{k}$ denotes group k's share of tax payments $i$ in year $t$ and $\beta_{j t}^{k}$ denotes its share of government expenditures $j$ received, so that $\sum_{k=1}^{K} \alpha_{i t}^{k}=1$ for every type of tax payment $l$ and $\sum_{k=1}^{K} \beta_{j t}^{K}=1$ for every type of government expenditures $j$. Although $r e v_{i t}$ and $\exp _{j t}$ are observable in the data (see Section 2), we need to estimate the apportioning coefficients $\alpha_{i t}^{k}$ and $\beta_{j t}^{k}$, which we can then use to estimate the total revenues and expenditures, $R E V_{t}^{k}$ and $E X P_{t}^{k}$ for each group. These calculations allow us to compute the net fiscal contribution of every group $k$ in year $t, G S U R_{t}^{k}$.

Because the amount of the net fiscal contribution of each group obviously depends on group size, an interesting metric for assessing the relative size of the net fiscal contribution made by each population group $k$ is the ratio of revenues to expenditures paid in every year:

$$
R E_{t}^{k}=R E V_{t}^{k} / E X P_{t}^{k}
$$

where $R E_{t}^{k}$ indicates the share of revenues the government received in year $t$ from group $k$ relative to the expenditures made in favour of that group. As discussed in subsection 1.1.3, the net fiscal contribution of any population group in any fiscal year is determined by whether the government runs a deficit in that particular year. Therefore, to assess the relative contribution of a particular group, we also compute the ratio between $R E_{t}^{k}$ for a particular immigrant group $k$ and the native population:

$$
R R E_{t}^{k}=R E_{t}^{k} / R E_{t}^{N}
$$

where the index $N$ stands for natives.

\subsubsection{Measurement}

To measure the net fiscal contribution of immigrants and natives, we first group government receipts into the eight categories listed below, for each of which we compute a different apportioning coefficient $\alpha_{i t}^{k}$ (see Section 2 for our data sources, Appendix A for details on constructing the apportioning coefficients, and Appendix Tables A3 and A4 for details of items included in each revenue and expenditures category respectively):

(1) 'Income tax and National Insurance Contribution payments' represent almost $45 \%$ of total government revenues. We estimate each group's share of total

\footnotetext{
${ }^{18}$ For instance, in analysing the net fiscal contributions of immigrants who arrived since 2000, we distinguish between natives, non-EEA immigrants, immigrants from A10 and immigrants from the remainder of the EEA.
} 
payments from the LFS data by applying year-specific National Insurance Contribution (NIC) and income tax rates and allowances to individual wages. Because the LFS has no information on self-employment income and on other incomes beside employee's earnings, in our central scenario, we apportion the overall revenues from income taxes and NIC using the share of payments estimated on the sample of employees only. As a robustness check, however, we also report estimates in which we impute self-employment income based on sector of activity and the state pension income to pension recipients and then use these to compute the apportioning coefficients. ${ }^{19}$

(2) 'VAT and excise duties' account for $28 \%$ of total government revenues. We estimate each group's share of payments for each of these consumption taxes by applying the effective tax-specific rates by decile of household disposable income to the gross individual income from the LFS. As for income tax and $\mathrm{NIC}$, in our central scenario we use the information on employee wages that is directly available from the LFS to compute payments of VAT and other indirect taxes. Doing so, however, results in no estimated indirect tax payments for individuals with no employee income and an underestimation of total household income for households whose total income also includes transfers and self-employment income. Hence, we also perform robustness checks in which we impute both self-employment income based on sector of activity and state pension income to pension-age recipients. ${ }^{20}$ We compute effective tax rates for VAT and other indirect taxes as the ratio of the estimated amount paid by households in each income decile for each indirect tax to the average income of households in that decile. These data are available from the Office for National Statistics (ONS) publication The Effect of Taxes and Benefits on Household Income, which is based on the Expenditure and Food Survey. ${ }^{21}$ The implicit assumption underlying this strategy is that immigrants and natives with similar incomes have the same consumption pattern. However, some studies show that immigrants, especially those who have recently arrived or intend to return to their country of origin, may have lower consumption rates than natives with similar income. This difference in behaviour may arise partly due to remittances sent to the home country and partly due to higher labour market uncertainty leading to a higher level of precautionary savings (Dustmann, 1997; Carroll et al., 1999 for the US; Piracha and Zhu, 2012 for Germany; and Dustmann et al., 2014 for Italy). Because we have no direct source of information on immigrants' consumption patterns in the UK, we construct an alternative scenario in which we

${ }^{19}$ Because we have no information on either years of NIC contributions or pension category, we impute the full amount of category A basic state pension to all pension-age individuals in the LFS who declare they are receiving pension benefits. The results, therefore, are likely to overestimate the actual amount of state pension transfers received.

${ }^{20}$ It should be noted that state pension is the largest single transfer received by households across all income deciles.

21 The Effect of Taxes and Benefits on Household Income is available at http://www.ons.gov.uk/ons/rel/ household-income/the-effects-of-taxes-and-benefits-on-household-income/historical-data/sum-historical-tab les.html. 
assume that the consumption of immigrants arrived since 2000 is only $80 \%$ that of natives with a similar income. ${ }^{22}$

(3) 'Company and capital taxes' represent about 9\% of total government revenues. The allocation of corporate taxation raises complicated questions of incidence that are the subject of several studies in the specialised literature. However, although there is consensus that some of the corporate income tax burden is shifted away from shareholders, there is no agreement about how it is shared between shareholders, workers and consumers (Harberger, 1962, 2008; Auerbach, 2006; Gravelle, 2011, 2013; Arulampalam et al., 2012). In our analysis, therefore, we take no stance on this open debate and apportion these tax payments, net of the percentage likely to be paid by foreign shareholders which ranges between $16 \%$ and $40 \%$, on a per capita basis among the adult population. ${ }^{23}$ One way of interpreting this choice is that we implicitly assume that company ownership (i.e. share ownership) is similarly distributed between the native and immigrant population. Alternatively, it could be seen as capturing the fact that the real burden of corporate taxes may fall ultimately on consumers and must thus be shared on a per capita basis. As a robustness check, we also compute the apportioning coefficient for company and capital taxes under the (possibly extreme) assumption that immigrants who have been in the UK for less than 10 years do not own any shares of British companies, and that, more generally, they do not bear any burden of corporate taxation. In this alternative scenario, therefore, we apportion company and capital tax payments, net of the share likely paid by foreign shareholders, proportionately to the population that has been in the UK for more than 10 years (i.e. natives and long-term immigrants).

(4) 'Council tax' payments, levied on domestic residences by individual local authorities dependent on the value of the property, make up slightly more than $4 \%$ of total government revenues. Because we have no detailed information on individual housing value or local tax levels, we abstract from such differences and simply estimate each group's share of council taxes as proportional to the number of households in the group.

(5) 'Business rates', a tax on non-domestic property typically paid by businesses and other organisations that occupy non-domestic premises, represent about $4 \%$ of total government revenues. We treat these payments similarly to company and capital tax payments. Hence, in our central scenario, we apportion them proportionately to the adult population, while in a robustness check, we allocate them to native and long-term immigrants only (i.e. those in the UK for more than 10 years).

(6) 'Gross operating surplus and rents and interests and dividends' amount to $5 \%$ of total government revenues. As explained in subsection 1.1.4, we apportion

\footnotetext{
${ }^{22}$ The estimates for Germany in Piracha and Zhu (2012) imply that immigrant consumption is about $90 \%$ of native consumption. Hence, in the absence of estimates for the UK, we choose a fraction that should, if anything, underestimate immigrants' consumption and thus their tax payments.

23 The share of foreign ownership in UK companies is available from the annual ONS Share Ownership report.
} 
the government's gross operating surplus and rents and interests and dividends proportionately to the share of each group in the adult (16+) population. When assessing the marginal fiscal effects of immigration, however, we attribute these revenues entirely to natives, thus implicitly assuming that they are the result of government operations undertaken before the immigrants' arrival.

(7) 'Inheritance tax' payments account for just $0.6 \%$ of total revenues. We use house ownership (from the LFS) as a proxy for asset ownership and apportion inheritance tax proportionately to the share of natives and immigrants over the age of 70 in the house-owner population.

(8) All remaining tax payments (4.7\% of total revenues), including landfill tax, climate change levy, aggregates levy, other taxes and royalties and other receipts, are apportioned according to the share of each group in the adult $(16+)$ population.

We group government expenditures in like manner, estimating a different apportioning coefficient $\beta_{j t}^{k}$ for each of the following eight categories (see Appendix A for details):

(I) 'Pure public goods and services' represent $16.5 \%$ of total government expenditures and include all public goods and services that are typically non-rival in consumption (see subsection 1.1.4). In our first scenario (the 'average effect scenario'), we apportion the cost of providing these goods proportionately to the share of each group in the adult $(16+)$ population. In our second scenario (the 'marginal effect scenario'), when we assume that the marginal cost of providing 'pure' public goods to immigrants is zero, we attribute these expenditures entirely to natives.

(II) 'Congestible public goods and services', publicly provided goods and services that are to some extent rival in consumption, represent more than $14 \%$ of total government expenditures. We apportion the cost of providing these goods according to each group's share in the adult (16+) population.

(III) 'Medical and other health services' make up almost $17 \%$ of total government expenditures. According to Wadsworth (2013), age is a primary determinant of health status and of the demand for GP and hospital visits in the UK, and there are no large differences in health service use between immigrants and natives in similar age groups. We thus estimate the proportion of health services expenditure attributable to each group based on the group's age structure.

(IV) 'Education' represents $12 \%$ of total government expenditures. For compulsory education, we estimate each group's apportioning coefficient based on the share of its children in the relevant age bracket for each school level (0-4 for pre-primary, 5-15 for primary and secondary). For postsecondary education, we compute the share of the school population for each group using direct information from the LFS on type of school attended by those still in the education system.

( $V$ ) 'Social protection', which includes expenditure for sickness and disability, old age, family and children, unemployment, housing and social exclusion, makes up over $34 \%$ of government expenditures. Since about $85 \%$ of these 
expenditures are allocated in terms of cash benefits, we use LFS information on the receipt of different types of benefits and compute for each group the share among the total recipients of each type of benefit. Because we have no information on the amount of benefits received, we implicitly assume that every recipient receives the same amount. However, since the average amount of housing benefits receipts varies substantially across regions, when apportioning housing benefits, we first allocate housing benefits expenditures across regions and then simply assume that within the same region everyone receives the same amount. In a robustness check, we also account for the higher receipt of child benefits in families with more children and apportion the whole social expenditure on family and children among the recipients of income support or family-related benefits, proportionately to the number of dependent children.

(VI) 'Prisons and law courts' account for less than $2 \%$ of total government expenditures. We use information on the nationality of prison inmates from the Ministry of Justice's Offender Management Caseload Statistics and apportion prison costs proportionately to the size of each group in the prison population. ${ }^{24}$

(VII) 'Housing development', which comprises expenditures for social and local authority housing, accounts for about $1 \%$ of total expenditures. We estimate each group's share of total costs based on its share of social housing tenants reported in the LFS.

(VIII) 'Police services' account for $3 \%$ of total government expenditures. Since most police services are equally used by immigrants and natives, we attribute their cost on a per capita basis. However, since 'immigration-related police services' are separately reported as a sub-item of expenditure for police services, we attribute their cost only to immigrants.

\section{Data}

Our primary data source, the UK Labour Force Survey (LFS), is a quarterly representative survey of about 60,000 households in the UK or about $0.2 \%$ of the UK population. This survey records respondents' labour market status and wages, as well as their personal and household circumstances, including country of birth and year of arrival in the UK if applicable, although not parental country of birth (see subsection 1.1.1). It also gathers self-reported information on any type of state benefit or tax credit received as well as type of accommodation, which we use to identify individuals living in social housing. Information on receipt of state benefits, however, has been available only since 1998, whereas information on social housing exists for all the years considered in our analysis. We, therefore, increase the sample size by pooling the four quarterly waves in every fiscal year, which in the UK begins in April. Hence, for fiscal year $t$, we pool LFS quarters 2, 3 and 4 of year $t$ and quarter 1 of year $t+1$. We use the LFS as the main source of information on native and immigrant population

\footnotetext{
${ }^{24}$ Offender Management Caseload Statistics are available at https://www.gov.uk/government/publications/offender-management-statistics-quarterly-2.
} 
characteristics and rely on it for both a description of UK immigration and an analysis of the probability of welfare and social housing receipt. We also employ it as the basis for many of the apportioning coefficients in the fiscal cost and benefits analysis.

For the fiscal analysis, we use administrative data on government receipts and expenditures; particularly, information on current government revenues for the fiscal years 2010 and 2011 from the March 2012 and December 2012 Office for Budget Responsibility's Economic and Fiscal Outlooks, ${ }^{25}$ respectively. For earlier fiscal years, we rely on information for all years between 1995 and 2009 available in Table C4 of the now-discontinued Public Finances Databank, a compilation of data published by the ONS that covers the main aspects of government finances, including receipts, expenditure, borrowing and debt as provided by HM Treasury.

We derive our public expenditure data from the 'Total Expenditure on Services by Sub-function' Table of the Public Expenditure Statistical Analyses (PESA), also published annually by HM Treasury. These Tables report expenditures for different items classified according to the United Nations Classification of the Functions of Government (UN COFOG) definitions at level 2. ${ }^{26}$ We use PESA 2012 (Table 5.2) for years 2007-11, PESA 2009 (Table 5.2) for years 2003-6, PESA 2004 (Table 3.6) for years 1998-2002 and PESA 1999-2000 (Table 4.5) for years 1995-7. ${ }^{27}$

\section{Immigration to the UK}

Since the late 1980s, when net migration to the UK was close to zero or even negative for some years, immigration has been steadily rising. This rise is evident in Table 1, which reports the evolution of the adult (age 16+) UK population since 1995 based on figures from the LFS. As the first column shows, over the past 15 years, the native adult population has grown slightly from less than 42 million in the late 1990s to more than 43 million in 2011. The immigrant population, on the other hand, has almost doubled over that period, from about 3.5 million in 1995 to almost 7 million in 2011, an increase from $7.8 \%$ to $13.8 \%$ of the adult population in 17 years. Breaking these figures down into EEA versus non-EEA immigrants, in 1995, the former made up $20 \%$ of the total UK immigrant population but more than tripled between 1995 and 2011, growing from 723,000 to 2.3 million. Over that same period, the non-EEA population grew at a considerably lower rate, increasing from 2.8 million to 4.6 million, so that by 2011, 33\% of the immigrant population was composed of EEA immigrants. However, as shown in the last three columns of panel $(a)$, which also distinguish between A10 and other EEA immigrants, the number of those who entered since 2000 and were still in the UK in 2011 was in excess of 1.2 million for EEA (including 900,000 A10) and 2.1 million for non-EEA immigrants. Hence, despite an increase in EEA immigration,

\footnotetext{
25 Tables 4.7 and 4.6, respectively, available online at http://budgetresponsibility.independent.gov.uk/ pubs/December-2012-EFO-charts-and-tables2342.xls and http://budgetresponsibility.independent.gov.uk/ pubs/March-2012-EFO-charts-and-tables.xls.

${ }^{26}$ Prior to the PESA 2007 adoption of the UN COFOG classification, government functions were categorised based on an HMT classification. We, therefore, used the mapping in the HMT technical manual to construct a consistent classification over time.

${ }_{27}$ Recent PESA are available online at https://www.gov.uk/government/organisations/hm-treasury/ series/public-expenditure-statistical-analyses-pesa.
} 
Table 1

Native and Immigrant Population Size and Employment

\begin{tabular}{|c|c|c|c|c|c|c|}
\hline $\begin{array}{l}\text { Fiscal } \\
\text { year }\end{array}$ & Natives & EEA & Non-EEA & $\begin{array}{l}\text { Recent } \\
\text { A10 }\end{array}$ & $\begin{array}{c}\text { Recent other } \\
\text { EEA }\end{array}$ & $\begin{array}{c}\text { Recent non- } \\
\text { EEA }\end{array}$ \\
\hline \multicolumn{7}{|c|}{ Panel (a): Total population above age 15} \\
\hline 1995 & $41,731,337$ & 723,429 & $2,804,323$ & & & \\
\hline 1996 & $41,820,718$ & 683,151 & $2,912,747$ & & & \\
\hline 1997 & $41,804,162$ & 775,922 & $3,001,483$ & & & \\
\hline 1998 & $41,843,948$ & 848,009 & $3,075,676$ & & & \\
\hline 1999 & $42,036,093$ & 867,256 & $3,088,988$ & & & \\
\hline 2000 & $42,133,257$ & 869,829 & $3,260,681$ & & & \\
\hline 2001 & $42,246,760$ & 924,196 & $3,394,871$ & 20,735 & 71,263 & 279,550 \\
\hline 2002 & $42,311,144$ & 963,843 & $3,577,689$ & 32,025 & 105,698 & 495,818 \\
\hline 2003 & $42,519,121$ & $1,002,192$ & $3,643,040$ & 43,091 & 132,770 & 680,678 \\
\hline 2004 & $42,718,610$ & $1,044,713$ & $3,775,507$ & 97,579 & 162,778 & 890,617 \\
\hline 2005 & $42,789,577$ & $1,184,864$ & $3,991,354$ & 228,030 & 188,691 & $1,063,881$ \\
\hline 2006 & $42,817,091$ & $1,408,846$ & $4,130,452$ & 373,999 & 207,724 & $1,285,525$ \\
\hline 2007 & $42,802,420$ & $1,915,998$ & $4,048,336$ & 557,481 & 277,541 & $1,458,276$ \\
\hline 2008 & $42,932,555$ & $1,993,807$ & $4,255,532$ & 617,986 & 293,178 & $1,698,981$ \\
\hline 2009 & $43,240,202$ & $2,002,183$ & $4,306,962$ & 640,116 & 301,718 & $1,815,423$ \\
\hline 2010 & $43,390,160$ & $2,155,913$ & $4,373,211$ & 778,315 & 333,369 & $1,886,609$ \\
\hline 2011 & $43,353,837$ & $2,314,078$ & $4,600,469$ & 892,984 & 366,768 & $2,127,783$ \\
\hline \multicolumn{7}{|c|}{ Panel (b): In employment } \\
\hline 1995 & $23,946,910$ & 377,016 & $1,435,154$ & & & \\
\hline 1996 & $24,175,597$ & 356,050 & $1,509,346$ & & & \\
\hline 1997 & $24,493,559$ & 419,926 & $1,572,652$ & & & \\
\hline 1998 & $24,690,541$ & 468,586 & $1,622,111$ & & & \\
\hline 1999 & $25,038,104$ & 488,194 & $1,619,874$ & & & \\
\hline 2000 & $25,206,296$ & 498,991 & $1,736,418$ & & & \\
\hline 2001 & $25,327,693$ & 529,538 & $1,794,351$ & 12,063 & 46,884 & 141,734 \\
\hline 2002 & $25,411,844$ & 561,189 & $1,928,792$ & 21,769 & 67,280 & 267,517 \\
\hline 2003 & $25,610,365$ & 571,608 & $1,995,494$ & 27,198 & 88,329 & 385,602 \\
\hline 2004 & $25,716,260$ & 636,934 & $2,114,309$ & 71,204 & 113,786 & 518,913 \\
\hline 2005 & $25,781,387$ & 762,027 & $2,199,151$ & 186,344 & 130,304 & 621,134 \\
\hline 2006 & $25,682,447$ & 934,123 & $2,338,403$ & 314,088 & 142,031 & 780,867 \\
\hline 2007 & $25,674,649$ & $1,248,355$ & $2,320,422$ & 465,790 & 195,136 & 884,941 \\
\hline 2008 & $25,535,639$ & $1,300,595$ & $2,457,685$ & 515,594 & 214,211 & $1,028,846$ \\
\hline 2009 & $25,105,774$ & $1,286,007$ & $2,413,828$ & 520,730 & 204,572 & $1,064,516$ \\
\hline 2010 & $25,132,741$ & $1,411,720$ & $2,495,924$ & 638,575 & 229,294 & $1,127,779$ \\
\hline 2011 & $24,966,418$ & $1,518,116$ & $2,576,056$ & 724,607 & 252,557 & $1,242,846$ \\
\hline
\end{tabular}

Notes. The Table reports in panel $(a)$ the number of UK natives and of EEA and non-EEA immigrants over the age of 15 in every fiscal year. We define as immigrants foreign-born individuals. In panel $(b)$, we report the number of individuals over the age of 15 who are employed or self-employed in each group. The three rightmost columns in each panel refer to recent immigrants, defined as those arrived since 2000, and distinguish between A 10 immigrants and other EEA immigrants. Source. UKLFS, several years.

non-EEA net immigration was nearly twice as large as EEA net immigration during that decade. Likewise, of the new EEA immigrants entering the UK during the 2000-11 period, the majority came from an A10 country, with more than 890,000 A10 immigrants entering and remaining in the UK versus a net inflow of other EEA immigrants of just above $360,000 .^{28}$

\footnotetext{
28 Because the first two columns include all immigrants but the last three columns only immigrants who arrived after 2000, the differences in populations between 2011 and 2001 vary due to out-migration of immigrants who have been in the UK before 2001.
}

(C) 2014 Royal Economic Society. 
Table 2

Length of Residence in the UK for the Adult Immigrant Population

\begin{tabular}{|c|c|c|c|c|c|c|}
\hline \multirow[b]{2}{*}{ Fiscal year } & \multicolumn{3}{|c|}{ Median years since migration } & \multicolumn{3}{|c|}{ Proportion $0-5$ years } \\
\hline & $\operatorname{Imm}$ & EEA & Non-EEA & $\mathrm{Imm}$ & EEA & Non-EEA \\
\hline 1995 & 24 & 28 & 23 & 0.16 & 0.17 & 0.16 \\
\hline 1996 & 24 & 28 & 24 & 0.16 & 0.17 & 0.15 \\
\hline 1997 & 24 & 27 & 23 & 0.16 & 0.19 & 0.16 \\
\hline 1998 & 24 & 25 & 23 & 0.18 & 0.22 & 0.16 \\
\hline 1999 & 23 & 25 & 23 & 0.18 & 0.22 & 0.17 \\
\hline 2000 & 23 & 26 & 22 & 0.20 & 0.24 & 0.19 \\
\hline 2001 & 22 & 24 & 21 & 0.22 & 0.24 & 0.21 \\
\hline 2002 & 20 & 22 & 20 & 0.24 & 0.25 & 0.23 \\
\hline 2003 & 19 & 22 & 18 & 0.25 & 0.24 & 0.25 \\
\hline 2004 & 17 & 18 & 17 & 0.27 & 0.28 & 0.26 \\
\hline 2005 & 16 & 13 & 16 & 0.28 & 0.34 & 0.26 \\
\hline 2006 & 15 & 11 & 15 & 0.29 & 0.38 & 0.26 \\
\hline 2007 & 13 & 12 & 14 & 0.30 & 0.39 & 0.25 \\
\hline 2008 & 13 & 11 & 13 & 0.29 & 0.38 & 0.25 \\
\hline 2009 & 12 & 11 & 13 & 0.27 & 0.35 & 0.24 \\
\hline 2010 & 12 & 10 & 13 & 0.25 & 0.34 & 0.21 \\
\hline 2011 & 12 & 9 & 13 & 0.24 & 0.30 & 0.21 \\
\hline
\end{tabular}

Notes. The Table reports for all immigrants, EEA immigrants and non-EEA immigrants over the age of 15, the median years since migration and the proportion of population who have been in the UK for five years or less. Source. UKLFS, several years.

As indicated in Table 1, panel (b), migration has also contributed substantially to overall employment. About 2.3 million new jobs created since 1995 went to immigrants, and about 1 million jobs created over the same period went to natives, which is not surprising given that (as panel (a) shows) immigration is primarily responsible for the growth in the UK working age population. More specifically, the number of employed individuals from the EEA increased fourfold, from 377,000 to 1.5 million, while the number of employed non-EEA increased by almost $80 \%$, from 1.5 to 2.6 million. ${ }^{29}$ The median length of immigrant stay in the UK decreased quite dramatically, from 24 to 12 years between 1995 and 2011 (see Table 2). At the same time, the proportion of immigrants staying for less than 5 years increased from $16 \%$ in 1995 to $24 \%$ in 2011. Breaking these numbers down for immigrants from EEA versus non-EEA countries suggests that this change in average duration can be attributed primarily to the relative increase in EEA immigrants since the mid-2000s. That is, by 2011, EEA immigrants' median UK residence had reduced by over two-thirds, from 28 to 9 years, while that for non-EEA immigrants had dropped by 44\%, from 23 to 13 years. In this same year, about $30 \%$ of EEA and $21 \%$ of non-EEA immigrants had been in the UK for at most 5 years, up from $17 \%$ and $16 \%$ respectively, in 1995 .

According to Table 3, which reports the demographic characteristics of immigrant populations to the UK, the UK's immigrant population has, perhaps not surprisingly,

\footnotetext{
29 These figures illustrate the irrelevance of the 'lump labour fallacy'; that is, that the amount of work to workers is fixed. Rather, the numbers suggest that employment has increased even more than population growth through immigration: between 1995 and 2011, the total adult UK population (including immigrants) increased by $11.1 \%$ and the total working age (16-65) population increased by $10.2 \%$, while the total number of jobs increased by $12.8 \%$.
} 
THE ECONOMIC JOURNAL

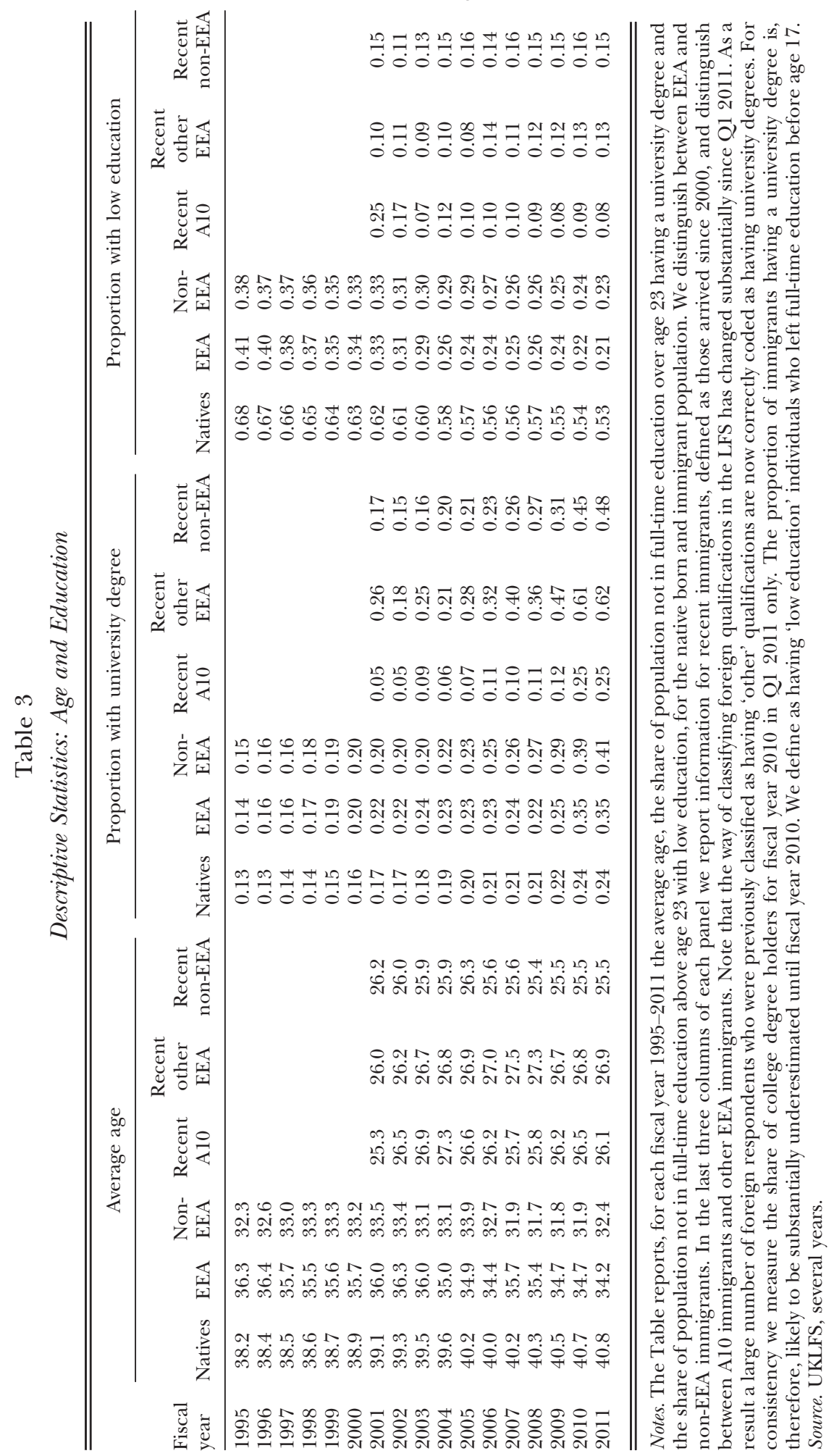


been consistently younger than the native population. Moreover, despite clear evidence for ageing in the native born population (with the average age increasing by 2.5 years, from 38.2 to 40.8 ), the age of the non-EEA population has remained roughly constant at 32-34 years, while that of the EEA population decreased from 36.3 years in 1995 to 32.3 years in 2011. This demographic trend in the immigrant population is due partly to return migration and partly to the younger age of recently arrived immigrants, who are on average younger than their co-nationals who have been in the UK for longer. For example, the average age of recent (i.e. those arrived since 2000) non-EEA immigrants has remained constant at around 26 years for all years, while the average age of recent EEA immigrants, although it has now stabilised at just above 26 years, fluctuated between about 25 and 27 up until 2004. Interestingly, recently arrived A10 immigrants are on average almost one year younger than those who have arrived since 2000 from other EEA countries.

Even more remarkable is the immigrant population's educational achievement, which has been consistently higher than that of the native population since 1995, with an increasing gap ever since. Whereas in 1995, about $13 \%$ of the UK born and $14 \%$ of the EEA immigrant population (excluding those still in full-time education) held a university degree, such was the case for $15 \%$ of the non-EEA population. By 2011, the percentage of natives with a degree had nearly doubled, to $24 \%$, while the percentage of EEA and non-EEA immigrants had increased even further, to $35 \%$ and $41 \%$ respectively. ${ }^{30}$ It should be noted, however, that substantial changes to the LFS classification of foreign qualifications effective since Q1 2011 have resulted in a large number of foreign respondents, previously classified as having 'other' qualifications, now being correctly coded as having university degrees. The proportion of these immigrants is thus likely to be substantially underestimated until the fiscal year $2010 .{ }^{31}$ Similarly, about one in two native born individuals fall into the 'low education' category (defined as those who left full-time education before age 17), while only one in five EEA immigrants and one in four non-EEA immigrants do so. A10 immigrants who arrived since 2000 include a lower share of university graduates (25\% in 2011) but also a substantially lower share of 'low education' individuals (around 10\% in all years) than recent immigrants from other EEA countries $(62 \%$ of whom had a degree and $13 \%$ a low level of education in 2011). Recent non-EEA immigrants, although they show similar rates of university degrees as earlier immigrants, include a considerably lower share of 'low education' individuals.

As Table 4 clearly shows, however, these stark educational differences between immigrants and natives are not reflected by wage differences: the median wages of natives and non-EEA immigrants are nearly the same, while the median wages for EEA immigrants are below those of natives, by about $16 \%$ in 2011 . One possible reason for these wage differences relative to the considerable educational differences is the age structure: many of these immigrants are young enough that their career profiles have

\footnotetext{
30 The different age structure of the native and immigrant population is not the only reason for these differences. For instance, in 2011, even within the 25-45 age bracket, the percentage of natives with a degree is $30 \%$, whereas the respective shares for EEA and non-EEA immigrants are $40 \%$ and $46 \%$.

31 For consistency in the qualification variable, we measure the share of college degree holders for fiscal year 2010 in Q1 2011 only.
} 
THE ECONOMIC JOURNAL

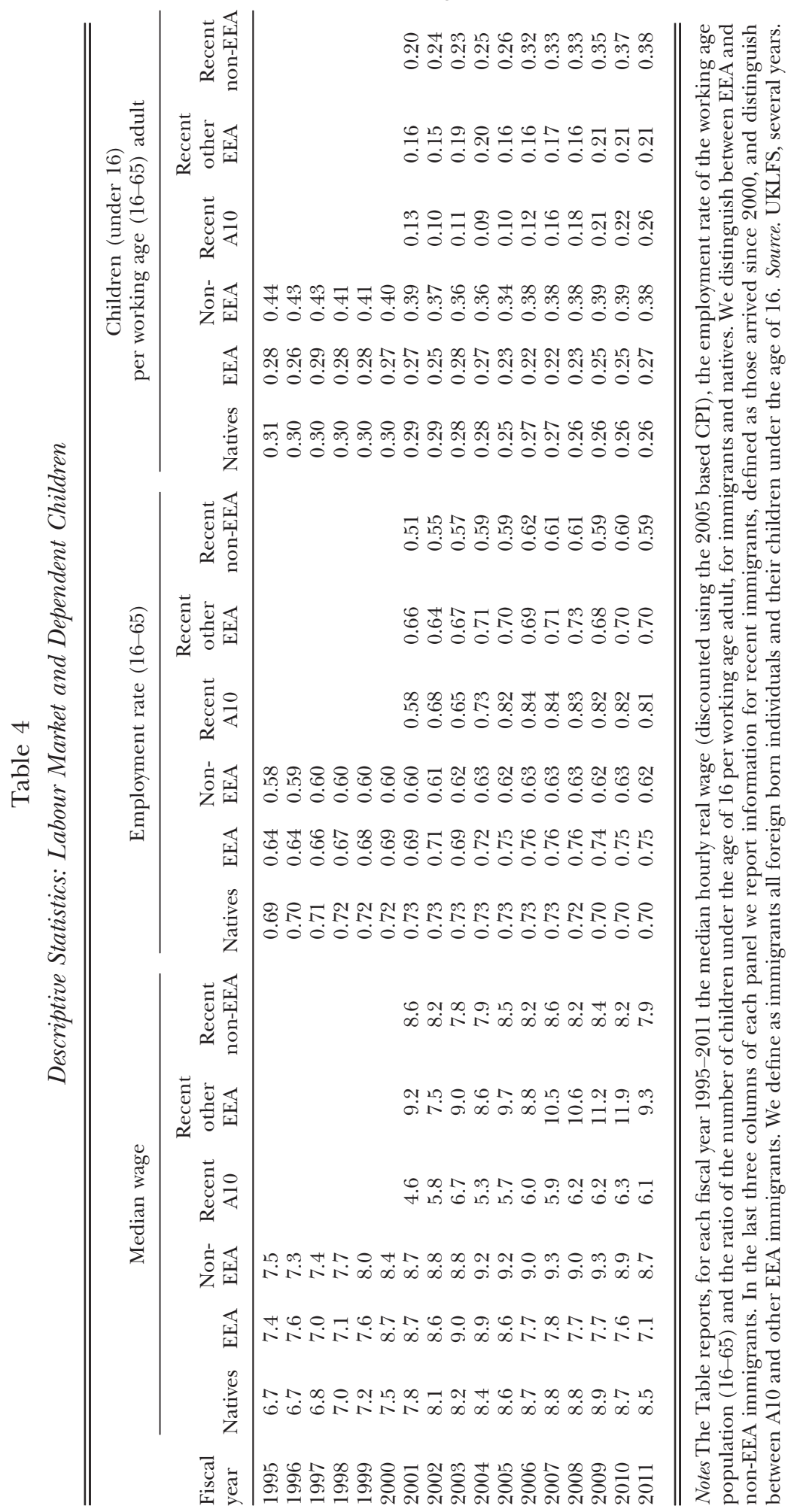

(C) 2014 Royal Economic Society. 
not yet peaked. Another reason may be occupational downgrading of immigrants who have spent only a short time in the UK because of factors (e.g. language proficiency) that prevent them putting their qualifications to the most productive use. This latter explanation is supported by the larger wage gap suffered especially by recent A10 and, to a lesser extent, by recent non-EEA immigrants with respect to their co-nationals who have been in the UK longer.

Since the mid-2000s, employment rates have also been slightly higher for EEA immigrants than for natives, $75 \%$ versus $70 \%$ in 2011 (see Table 4). The employment rate of non-EEAs, on the other hand, is lower in all years, only 62\% in 2011. Interestingly, although in all years, recent A10 immigrants have lower wages than earlier immigrants, they have considerably higher employment rates, especially in recent years when they are above $80 \%$. Conversely, over the same period, the employment rate of recent immigrants from the other EEA countries and of non-EEA immigrants has hovered at consistently lower levels, around $70 \%$ and $60 \%$, respectively.

In the rightmost panel of Table 4, we report the ratio of children under 16 to the working age (16-65) population of each group, a ratio that in all years is substantially larger for non-EEA immigrants than for natives and EEAs. In 2011, for instance, the fraction of non-EEA children to adults is $0.38,12$ percentage points higher than for natives and 11 percentage points higher than for EEA immigrants. Nevertheless, it is also important to note that this ratio is lower for recent immigrants, especially in the first years after arrival when they are younger.

The figures reported above raise a number of important issues: first, not only is the demographic structure of the immigrant versus the native population quite different, but the demographic features of the immigrant population have shifted quite dramatically over the last 1.5 decades towards a younger and better educated population. This shift also means, however, that immigrants are likely to be at earlier stages of their career profiles, which, as previously mentioned, may explain relatively modest wages despite strong educational backgrounds. With time spent in the UK, immigrants' wages are likely to experience a faster growth than natives', thereby rapidly enhancing their fiscal contribution. For instance, we find that between 2001 and 2011, the average annual wage growth of recent immigrants to the UK was $1.2 \%$ higher per year than that of natives. ${ }^{32}$ The profile of immigration over the last decade also indicates that today's immigrants are relatively recent arrivals in the UK, which again may affect their earnings potential through initial downgrading (Dustmann et al., 2013). Their younger age may also imply a greater likelihood of having children under

\footnotetext{
32 This result, based on a sample of natives and recent immigrants who received their education abroad, is obtained by regressing log hourly wages on a dummy for recent immigrants, potential UK experience (computed as the difference between current age and the age at which individuals left full-time education for natives and as years since migration for immigrants) and potential experience squared, potential experience in the home country (set to zero for natives) and potential experience in the home country squared, the interaction of a recent immigrant dummy with potential UK experience and potential UK experience squared. The following control variables, interacted and not interacted with a recent immigrant dummy are also included: three education dummies (high, intermediate and low education), a gender dummy, the interaction of education and gender dummies, the interaction of education dummies with dummies for region of residence and year-quarter interaction dummies (see Chiswick, 1978, for a similar specification). We then evaluate the marginal effect of an additional year of UK experience at the mean of the variables for recent immigrants and for natives.
} 
16. Greater parental responsibilities may also partly explain the lower employment rates for non-EEA immigrants.

\section{Fiscal Impact of Immigration}

\subsection{Benefits and Social Housing}

We assess the degree of welfare dependency of immigrants relative to natives based on the responses in each LFS wave on whether individuals receive state benefits or live in social housing. We distinguish, as we explain above, two immigrant populations: all immigrants resident in the UK (for which we pool all available years; i.e. 1998-2011 for welfare receipt and 1995-2011 for social housing ${ }^{33}$ ) and recent (post-2000) arrival cohorts of immigrants. Panel $(a)$ in Table 5 displays the results for all resident immigrants and panel $(b)$, those for only the post-2000 arrival cohorts. For receipt of benefits, we report results for two specifications: estimates that condition on year and quarter effects only and estimates that additionally condition on a full set of dummies for five-year age groups interacted with gender dummies. The first set of results (column 1) thus accounts for seasonal and yearly variations in benefit receipt and can be interpreted as the weighted averaged difference across quarters in the probability of receiving benefits or living in social housing between immigrants and natives, conditioned on fluctuations in welfare receipt over time that affect immigrants and natives alike. The second set (column 2) represents hypothetical differences when the immigrant and native age distributions are kept the same, meaning that the estimated marginal effect can be interpreted as the differences in the probability of receiving state benefits or tax credits if immigrants had the same age and gender structure as natives.

For social housing, we perform the analysis at the household level, as we explain in subsection 1.2.1, and we report similar specifications, but further condition on regional dummies (column 4) and regional dummies plus age dummies (column 5). Conditioning on regional dummies accounts for the fact that $42 \%$ of the immigrant population live in London, which has a high density of socially housed individuals. ${ }^{34}$ These estimations, therefore, represent the hypothetical differences between immigrants and natives if their age distribution and geographic distributions were the same. Finally, in the last row of each panel, we report the predicted probability of welfare receipt or social housing occupancy for natives according to the specification considered. All the marginal effects reported in the Tables are evaluated at the average of the conditioning variables for natives.

\subsubsection{Overall immigrant population, all years}

The last row of panel $(a)$ in Table 5 shows that according to the LFS, over the years 1998-2011, 37\% of natives were receiving some type of state benefit or tax credit. The Table entries also indicate that even when we keep the age and gender structures the

\footnotetext{
33 We have no information on welfare receipt in the LFS before 1998.

34 Over $24 \%$ of native households in Greater London live in social housing, compared to a national average of $20 \%$. The proportion of native households in social housing is the same in Greater Manchester, and higher only in Tyne and Wear (32\%), South Yorkshire and the metropolitan countries of West Midlands $(26 \%)$ and Scotland $(28 \%)$.
} 
Table 5

Immigrants-Natives Differential in Probability of Claiming State Benefits/Tax Credits or Living in Social Housing

\begin{tabular}{|c|c|c|c|c|c|}
\hline & \multicolumn{2}{|c|}{$\begin{array}{l}\text { State benefits/tax } \\
\text { credits }\end{array}$} & \multicolumn{3}{|c|}{ Social Housing } \\
\hline & 1 & 2 & 3 & 4 & 5 \\
\hline \multicolumn{6}{|c|}{ Panel (a): Resident immigrant population, 1995-2011 } \\
\hline All immigrants & $\begin{array}{l}-0.030 * * * \\
(0.001)\end{array}$ & $\begin{array}{l}-0.034 * * * \\
(0.001)\end{array}$ & $\begin{array}{l}0.020 * * * \\
-0.001\end{array}$ & $\begin{array}{l}0.004^{* *} \\
-0.001\end{array}$ & $\begin{array}{l}0.012 \text { *** } \\
-0.001\end{array}$ \\
\hline EEA & $\begin{array}{l}-0.078^{* * * *} \\
(0.002)\end{array}$ & $\begin{array}{l}-0.078^{* * *} \\
(0.002)\end{array}$ & $\begin{array}{l}-0.026^{* * *} \\
-0.002\end{array}$ & $\begin{array}{l}-0.031 * * * \\
-0.002\end{array}$ & $\begin{array}{l}-0.029 * * * \\
-0.002\end{array}$ \\
\hline Non-EEA & $\begin{array}{l}-0.013 * * * \\
(0.001)\end{array}$ & $\begin{array}{l}-0.019 * * * \\
(0.001)\end{array}$ & $\begin{array}{l}0.034 * * * \\
-0.002\end{array}$ & $\begin{array}{l}0.015^{* * * *} \\
-0.002\end{array}$ & $\begin{array}{l}0.026 \text { *** } \\
-0.002\end{array}$ \\
\hline $\begin{array}{l}\text { Predicted probability of } \\
\text { receipt for natives }\end{array}$ & 0.372 & 0.373 & 0.185 & 0.187 & 0.186 \\
\hline$N$ & $4,845,620$ & $4,845,620$ & $3,572,692$ & $3,572,692$ & $3,572,692$ \\
\hline \multicolumn{6}{|c|}{ Panel (b): Immigrants arrived in years 2000 onwards, 2001-11 } \\
\hline All immigrants & $\begin{array}{l}-0.174 * * * \\
(0.002)\end{array}$ & $\begin{array}{l}-0.155^{* * *} \\
(0.002)\end{array}$ & $\begin{array}{l}-0.012 * * * \\
(0.003)\end{array}$ & $\begin{array}{l}-0.024 * * * \\
(0.003)\end{array}$ & $\begin{array}{l}-0.011 * * * \\
(0.003)\end{array}$ \\
\hline A 10 & $\begin{array}{c}-0.165^{* * * *} \\
(0.003)\end{array}$ & $\begin{array}{c}-0.131 * * * \\
(0.004)\end{array}$ & $\begin{array}{c}-0.061 * * * \\
(0.005)\end{array}$ & $\begin{array}{c}-0.066^{* * * *} \\
(0.004)\end{array}$ & $\begin{array}{l}-0.055^{* * * *} \\
(0.005)\end{array}$ \\
\hline Other EEA & $\begin{array}{l}-0.243 * * * \\
(0.004)\end{array}$ & $\begin{array}{l}-0.232 * * * \\
(0.005)\end{array}$ & $\begin{array}{l}-0.093 * * * \\
(0.006)\end{array}$ & $\begin{array}{l}-0.098^{* * *} \\
(0.005)\end{array}$ & $\begin{array}{l}-0.085^{* * * *} \\
(0.006)\end{array}$ \\
\hline Non-EEA & $\begin{array}{c}-0.163 * * * \\
(0.002)\end{array}$ & $\begin{array}{l}-0.148 * * * \\
(0.003)\end{array}$ & $\begin{array}{l}0.017 * * * \\
(0.004)\end{array}$ & $\begin{array}{c}0.002 \\
(0.003)\end{array}$ & $\begin{array}{l}0.015^{* * *} \\
(0.004)\end{array}$ \\
\hline $\begin{array}{l}\text { Predicted probability of } \\
\text { receipt for natives }\end{array}$ & 0.403 & 0.400 & 0.175 & 0.175 & 0.175 \\
\hline Year and quarter effects & Yes & Yes & Yes & Yes & Yes \\
\hline Age & No & Yes & No & No & Yes \\
\hline Gender & No & Yes & No & No & No \\
\hline Region of residence & No & No & No & Yes & Yes \\
\hline$N$ & $3,451,264$ & $3,451,264$ & $1,973,356$ & $1,973,356$ & $1,973,356$ \\
\hline
\end{tabular}

Notes. The Table reports the gap in the probability of claiming state benefits/tax credits (columns 1 and 2) and in the probability of living in social housing (columns 3-5) between immigrants and natives. The units of observation are individuals for state benefits/tax credits and households for social housing. Panel (a) considers all immigrants, regardless of their year of arrival in the UK in fiscal years 1998-2011 (for state benefits) and 1995-2011 (for social housing), while panel (b) focuses on immigrants arrived in the UK since 2000. Estimates are obtained as marginal effects from a probit model, computed at the mean value of all the other regressors. 'Age' is a set of dummy variables for 5 years age groups starting at age 16, 'Gender' are gender dummies interacted with the full set of age dummies. 'Region of residence' are dummy variables for region of residence. Standard errors in parenthesis are clustered at the individual (for benefits) or household (for social housing) level. * Denotes significance at $10 \%,{ }^{* *}$ significance at $5 \%$ and ${ }^{* * *}$ significance at $1 \%$.

same, immigrants overall have a lower probability than natives of receiving state benefits or tax credits. Nonetheless, clear differences emerge between EEA immigrants, who are 7.8 percentage points less likely than natives to receive transfers or state benefits, and non-EEA immigrants, who are 1.3 percentage points less likely to be benefit recipients. When the same age and gender structure is maintained for immigrants and natives, the probability gap of EEA immigrants receiving state benefits or tax credits relative to natives does not change, while for non-EEA immigrants it increases slightly to -1.9 percentage points.

In columns 3-5, we report estimates in which the outcome variable is whether or not the respondent's household lives in social housing. Over the 1995-2011 period, the (C) 2014 Royal Economic Society. 
LFS indicates that just short of $19 \%$ of native households were living in social housing (last row, panel $(a)$ ). Although immigrants overall are slightly more likely to live in social housing (by 2 percentage points), stark differences again emerge between nonEEA immigrants, who are over 3 percentage points more likely to live in social housing, and EEA immigrants, who are almost 3 percentage points less likely to do so. This difference, however, may be attributable to immigrants being predominantly located in urban areas, especially London, where social housing is far more widespread than in the rest of the country. In fact, on average, over the years 1995-2011, London was home to $33 \%$ of EEA and $44 \%$ of non-EEA immigrant households, compared to just under $9 \%$ of natives. Indeed, when we condition on region of residence (column 4), the difference between immigrants and natives becomes negligible $(0.4$ percentage points), while non-EEA immigrants are slightly more likely and EEA immigrants less likely to live in social housing than natives. Conditioning additionally on average household age (thereby comparing immigrant and native households with the same average age structure and the same allocation across UK regions) minimally affects the results (see column 5).

\subsubsection{Recent arrival cohorts, years 2001-11}

For the more recently arrived cohorts (i.e. those who arrived since 2000), the pattern of estimates is similar but magnitudes differ. As panel (b), Table 5 shows, recent immigrants are far less likely than natives to draw state benefits or receive tax credits both overall (17 percentage points, column 1) and in comparison to natives with the same age structure (15.5 percentage points, column 2). Distinguishing between the different immigrant groups, A10 and non-EEA immigrants have about 16 percentage points lower probabilities of receiving transfer and tax credits than natives, whereas probabilities are considerably smaller (by about 23 percentage points) for immigrants from the other EEA countries. Recent immigrants overall are also 1.2 percentage points less likely than natives to live in social housing, a probability gap that increases to 6 percentage points for recent A10 immigrants and to more than 9 percentage points for recent immigrants from the rest of the EEA. Recent non-EEA immigrants, in contrast, are 1.7 percentage points more likely than natives to live in social housing. Yet again, the concentration in London leads to a slightly higher social housing uptake for all immigrant groups, as illustrated by the differences between columns 3 and 4 . Finally, the estimates in column 5 show that, even when we condition on age in addition to region of residence, recent immigrants overall are still less likely on average to live in social housing than natives.

\subsection{Expenditures and Revenues}

We now report our estimates of the net fiscal contribution for the different immigrant groups defined in subsection 1.1.2. We first discuss our basic specification, which allocates all public goods to immigrants according to their average cost and is thus, according to Rowthorn (2014), likely to overestimate the costs that these populations incur. In addition, while allocating the cost of educating their children to immigrants, we not only ignore the contributions that these children make but allocate these contributions to natives. We also ignore the savings for UK tax payers of immigrants 
arriving after having acquired education in their home country. In that sense, therefore, the estimates provided below are likely to be a lower bound for immigrant contributions. We will provide alternative estimates in the later Sections.

\subsubsection{Overall immigrant population, 1995-2011}

Our estimates for the overall immigrant population residing in the UK between 1995 and 2011 show that immigrants from EEA countries made a positive contribution over that period of more than $£ 4$ billion, while those from non-EEA countries made a negative contribution of $£ 118$ billion, compared to an overall negative native fiscal contribution of $£ 591$ billion (in 2011 equivalency) (panel (a), Table 6). ${ }^{35}$ However, as shown in Figure 1 $(a)$, which graphs the evolution of the revenues/expenditures ratio $\left(R E\right.$ in (4)) for the three groups from 1995 to $2011,{ }^{36}$ these contributions vary substantially over time. Over the 17 fiscal years considered, the amount of public expenditures received by natives exceeds the amount of government revenues they contributed in 12 instances. Although such is also the case for non-EEA immigrants for all 17 fiscal years, it applies to EEA immigrants only for seven years. One reason for these differences may be the higher fraction of children and lower employment rate in non-EEA households (as discussed in Section 3). Up until 2000, the relative fiscal contribution of natives was larger than the contributions of either EEA or non-EEA immigrants. However, since 2001, EEA immigrants have not only consistently had a higher revenues/expenditures ratio than natives but have often made positive fiscal contributions even in years when the amount of public expenditure on natives has been larger than natives' fiscal payments. On the other hand, the fiscal contribution of non-EEA immigrants is slightly negative in all years, although the difference between their net cost and that of natives has been closing over time. It is also worth noting that the three lines tend to co-move, reflecting the cyclicality of net fiscal revenues (see subsection 1.2.2). Nevertheless, even though the evolution of the net fiscal contribution of non-EEA immigrants closely mirrors that of natives, the fiscal contributions of EEA immigrants have strongly improved in relative terms over time. These trends are also evident from Figure 1b, which plots the relative revenues/expenditures ratio between EEA and non-EEA immigrants ( $R R E$ in (5)), defined as the revenues/ expenditures ratio for each immigrant group divided by the revenues/expenditures ratio for natives. In general, the Figure indicates that the relative position of both immigrant groups is improving steadily over time.

\subsubsection{Recent arrivals, years 2001-11}

When we focus on recent immigrant arrival cohorts (arrived since 2000), however, the picture changes drastically. As Figure 2(a) shows, in all fiscal years, recent immigrants from A10, other EEA or non-EEA countries have made higher relative fiscal contributions (as measured by $R E$ ) than natives. ${ }^{37}$ Recent European immigrants

\footnotetext{
35 See our discussion in subsection 1.1.2 about how to evaluate these results.

36 We report detailed Tables with annual estimated expenditures and revenues in Appendix Tables A5 and A6.

37 The only exception is for A10 immigrants in 2002 - a figure which is based on a very small number of observations because EU enlargement towards A8 countries did not occur until 2004.
} 
Table 6

Summary Results

\begin{tabular}{|c|c|c|}
\hline & \multicolumn{2}{|c|}{ Panel $(a)$ : 1995-2011 } \\
\hline & EEA & Non-EEA \\
\hline \multicolumn{3}{|c|}{ (1) Overall net fiscal contributions (£million, 2011 equivalent) } \\
\hline Average effect & 4,425 & $-117,961$ \\
\hline Marginal effect & 28,170 & $-59,618$ \\
\hline \multicolumn{3}{|c|}{ (2) Ratio of real revenues to real expenditures } \\
\hline Average effect & 1.018 & 0.846 \\
\hline Marginal effect & 1.137 & 0.912 \\
\hline \multicolumn{3}{|c|}{ (3) Revenues/expenditures ratio, relative to natives } \\
\hline Average effect & 1.098 & 0.912 \\
\hline Marginal effect & 1.237 & 0.992 \\
\hline \multicolumn{3}{|c|}{ (4) Educational savings (£million, 2011 equivalent) } \\
\hline Native-equivalent & 13,923 & 35,162 \\
\hline Actual education & 17,711 & 42,749 \\
\hline
\end{tabular}

Panel (b): 2001-11

\begin{tabular}{|c|c|c|c|c|}
\hline & Natives & Recent A10 & Recent other EEA & Recent non-EEA \\
\hline \multicolumn{5}{|c|}{ (1) Overall net fiscal contributions (£million, 2011 equivalent) } \\
\hline Average effect & $-616,529$ & 4,961 & 15,255 & 5,207 \\
\hline Marginal effect & $-679,109$ & 10,494 & 18,236 & 20,502 \\
\hline \multicolumn{5}{|c|}{ (2) Ratio of real revenues to real expenditures } \\
\hline Average effect & 0.895 & 1.120 & 1.640 & 1.033 \\
\hline Marginal effect & 0.886 & 1.319 & 1.946 & 1.154 \\
\hline \multicolumn{5}{|c|}{ (3) Revenues/expenditures ratio, relative to natives } \\
\hline Average effect & 1.000 & 1.252 & 1.833 & 1.154 \\
\hline Marginal effect & 1.000 & 1.487 & 2.196 & 1.302 \\
\hline \multicolumn{5}{|c|}{ (4) Educational savings (£million, 2011 equivalent) } \\
\hline Native-equivalent & & 4,307 & 2,498 & 11,189 \\
\hline Actual education & & 6,204 & 3,188 & 14,606 \\
\hline
\end{tabular}

Notes. Panel (a) reports, for natives, EEA and non-EEA immigrants, cumulated over fiscal years 1995-2011: (1) their overall net fiscal contribution, expressed in $£ 2011$ equivalent, (2) the ratio of revenues contributed to expenditures received, (3) the revenues/expenditures ratio for the respective immigrant group relative to natives. Under each heading, the 'Average effect' line reports estimates under the assumption that immigrants pay the average cost of public goods while the 'Marginal effect' line reports estimates under the assumption that they pay the marginal cost, assumed to be zero. The last two rows (4) report the cumulated annual implicit educational savings due to each immigrant group, when we consider the education of natives in their occupations (first line) and when we consider their actual level of education. Panel $(b)$ reports the same estimates for natives and recent immigrants (arrived since 2000), where we distinguish between A10, other EEA and non-EEA, and cumulated over fiscal years 2001-11.

particularly have made positive net fiscal contributions throughout the period. This observation holds true even in recent crisis years when the government has been running a budget deficit and the net fiscal contribution of natives - and to a lesser extent, recent non-EEA and recent A10 immigrants - has turned negative. Panel $(b)$ of Table 6 also shows that between 2001 and 2011, the overall contributions of recent A10 immigrants amounted to $£ 5$ billion, those of recent immigrants from the other EEA countries to $£ 15$ billion and those of recent non-EEA immigrants to over $£ 5$ billion. Interestingly, even throughout the crisis years 2007-2011, recent A10 immigrants made 

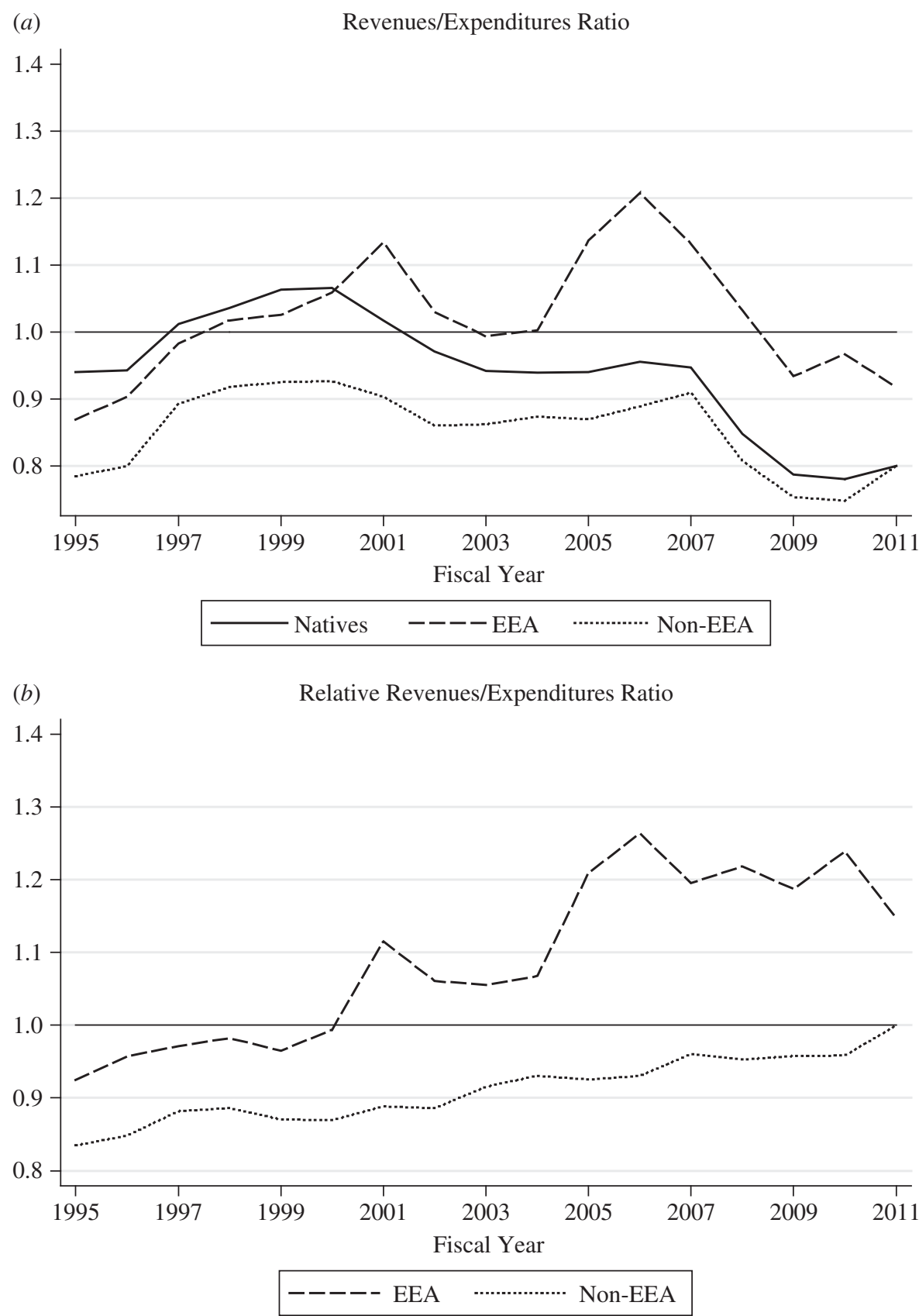

Fig. 1. (a) Ratio of Overall Revenues to Expenditures by Group (Average Effect Scenario). (b) Relative Immigrant/Native Ratio of Overall Revenues to Expenditures by Group (Average Effect Scenario) Notes. Figure $(a)$ reports for each fiscal year 1995-2011 the estimated ratio of public revenues to expenditures for natives, EEA and non-EEA immigrants when we impute to immigrants the average cost of public goods provision. Figure $(b)$ reports the revenues/expenditures ratio for each immigrant group relative to natives. 

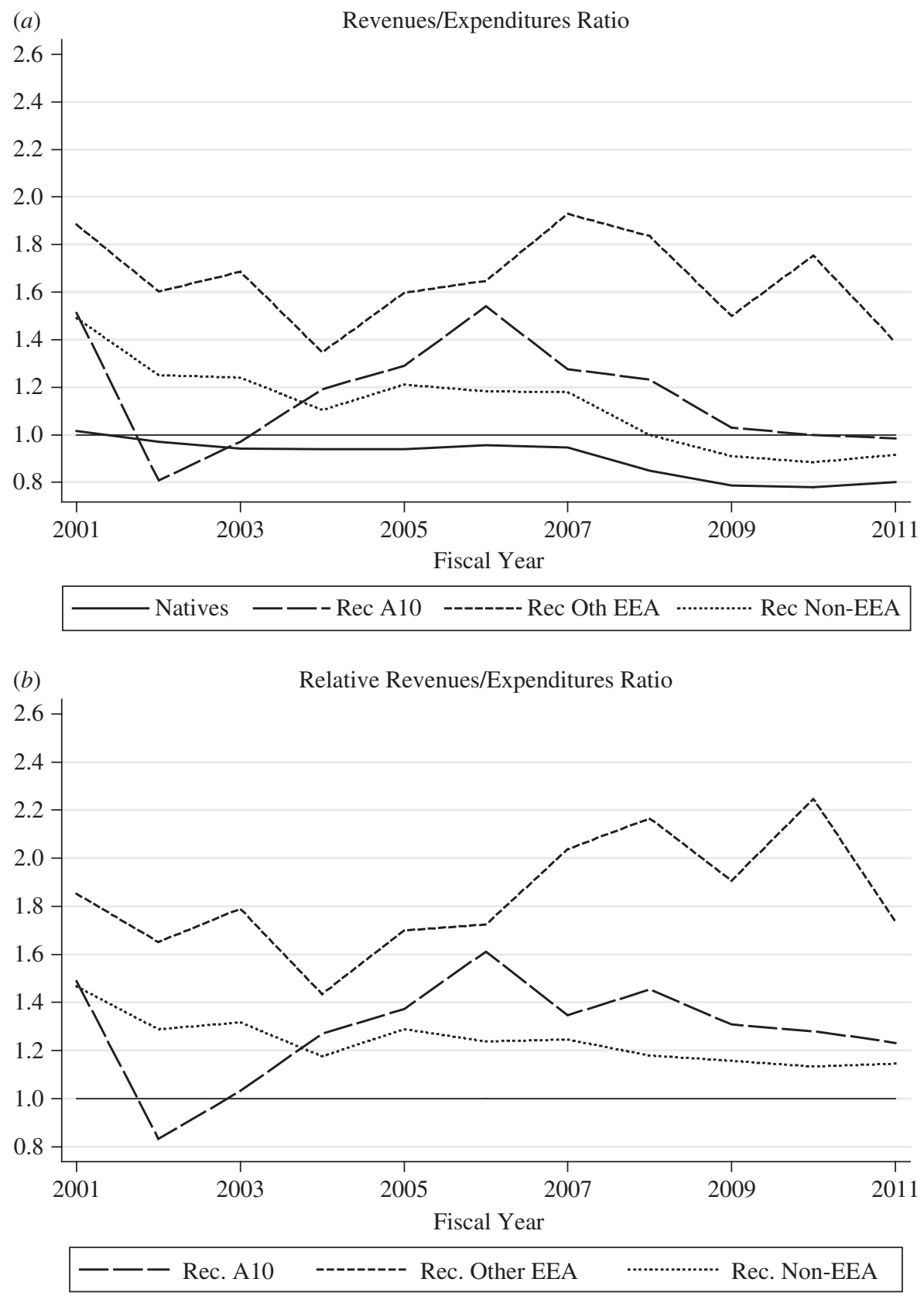

Fig. 2. (a) Ratio of Overall Revenues to Expenditures by Group (Recent Immigrants, Average Effect Scenario). (b) Relative Immigrants/Natives Ratio of Overall Revenues to Expenditures, by Group (Recent Immigrants, Average Effect Scenario)

Notes. Figure (a) reports for each fiscal year 2001-11 the estimated ratio of public revenues to expenditures for natives, and recent immigrants (arrived since 2000), where we distinguish between A10, other EEA and non-EEA immigrants, when we impute to immigrants the average cost of public goods provision. Figure $(b)$ reports the revenues/expenditures ratio for each immigrant group relative to natives.

(C) 2014 Royal Economic Society. 
a net contribution of almost $£ 2$ billion to UK public finances, while recent immigrants from the other EEA countries made a positive contribution of $£ 8.6$ billion.

In Figure 2(b), which reports the revenues/expenditures ratio of each immigrant group $(R R E)$ relative to that of natives, the difference for non-EEA immigrants is larger in the first years, reduces slightly over time, and then remains substantial throughout the period. Even in 2011, the revenues/expenditures ratio of recent non-EEA immigrants is $15 \%$ higher than that for natives. The relative contribution of recent A10 immigrants is also low in the first years but peaks in 2006 with a revenues/expenditures ratio about $60 \%$ higher than that of natives. The gap with respect to natives' relative contributions then shrinks over time, although in 2011, A10s are still paying $23 \%$ more than natives in relative terms. Interestingly, the relative payments of the other recently arrived EEA immigrants are not only consistently well above those of natives but their relative size has become increasingly larger over time, with just a slight drop in 2011. Thus, these figures point to recent immigrants, particularly those from EEA countries, contributing substantially more in terms of taxes than they have taken out in benefits and transfers over the period since 2000. This is the case even in years in which the UK ran a deficit and when the net fiscal contributions of natives were negative. Overall, therefore, the figures suggest that immigration since 2000, in particular from EEA countries, has helped reduce the fiscal burden for native workers and contributed to reducing the UK's fiscal deficit.

\subsubsection{Immigration's contribution to non-congestible public goods}

So far we have assumed that immigrants pay the average cost of all publicly provided goods and services. However, as discussed above, some of these, such as national defence, are non-congestible (see subsection 1.1.4), meaning that the cost of their provision is largely independent of the size of the UK's resident population. By attributing a proportional share of the cost of these non-congestibles to immigrants, therefore, we are likely to overestimate the effective fiscal costs of immigration because the actual marginal cost of their provision is probably close to zero. An alternative scenario would be one in which only the extra government expenditure resulting from the presence or arrival of immigrants is ascribed to immigrants (the 'marginal effect scenario' discussed in subsection 1.1.4). Clearly, in this alternative scenario, the net fiscal contributions of all immigrant groups will improve considerably at the expense of natives, who are now charged the full cost of pure public goods that they would have to bear in the absence of any immigrant population. It is also the scenario, however, that Rowthorn (2014) deems 'arguably superior' from a theoretical viewpoint. Figure 3 graphs the results of our analysis for using this alternative scenario for the immigrant population resident in the UK over the 1995-2011 period, while Figure 4 reports corresponding figures for the post-2000 immigrant cohorts. For brevity, panels $(a)$ and (b) of Table 6 summarise the findings for 1995-2011 and 2001-11; the detailed annual results are reported in Appendix Table A6.

As is obvious from Figure 3, the ratio of overall revenues to expenditure for non-EEA immigrants is now very close to that of natives, while the same ratio for EEA immigrants is clearly higher (and positive) for nearly all years. Figure 4, which illustrates the same statistics for the recently arrived cohorts, now shows a positive ratio for all immigrant groups, while the ratio remains negative for natives throughout the period. Addition- 
(a) Revenues/Expenditures Ratio
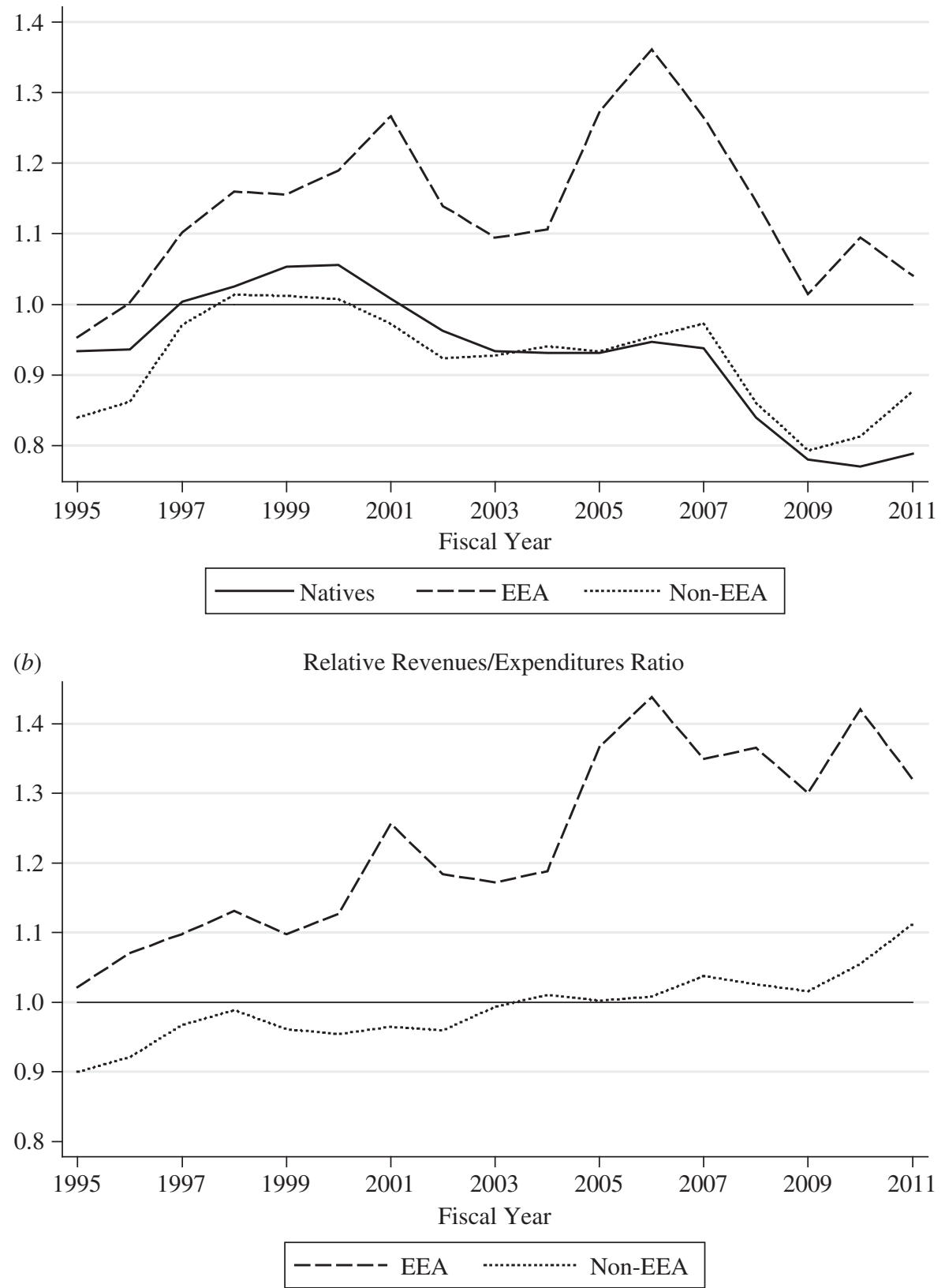

Fig. 3. (a) Ratio of Overall Revenues to Expenditures by Group (Marginal Effect Scenario). (b) Relative Immigrant/Native Ratio of Overall Revenues to Expenditures by Group (Marginal Effect Scenario) Notes. Figure (a) reports for each fiscal year 1995-2011 the estimated ratio of public revenues to expenditures for natives, EEA and non-EEA immigrants when we impute to immigrants the marginal cost of public goods provision. Figure $(b)$ reports the revenues/expenditures ratio for each immigrant group relative to natives. 
(a) Revenues/Expenditures Ratio
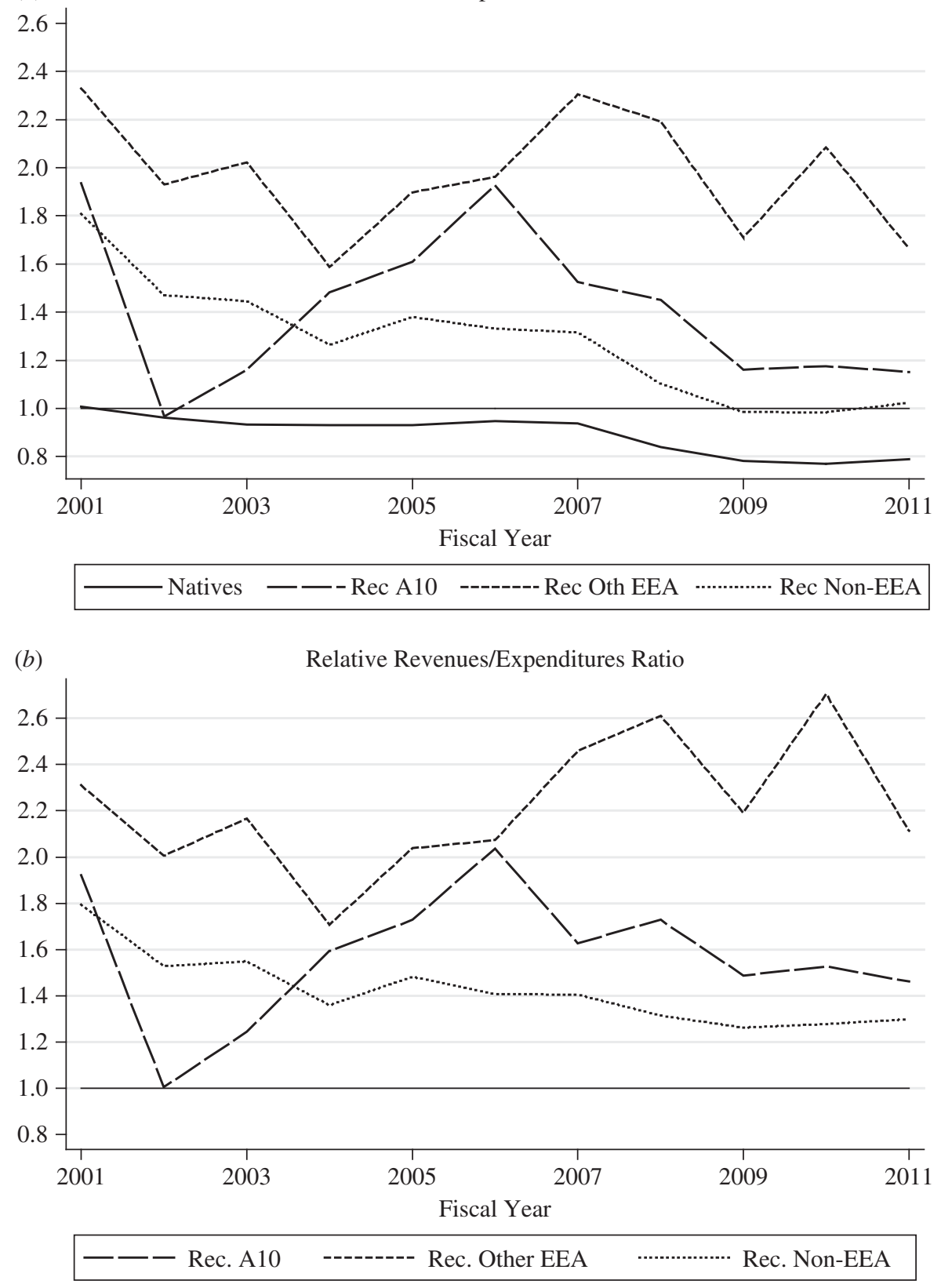

Fig. 4. (a) Ratio of Overall Revenues to Expenditures by Group (Recent Immigrants). (b) Relative Immigrants/Natives Ratio of Overall Revenues to Expenditures, by Group (Recent Immigrants) Notes. Figure $(a)$ reports for each fiscal year 2001-11 the estimated ratio of public revenues to expenditures for natives, and recent immigrants (arrived since 2000), where we distinguish between A10, other EEA and non-EEA immigrants, when we impute to immigrants the marginal cost of public goods provision. Figure $(b)$ reports the revenues/expenditures ratio for each immigrant group relative to natives. 
Table 7

Robustness checks: 1995-2011

\begin{tabular}{|c|c|c|c|}
\hline & Natives & EEA & Non-EEA \\
\hline \multicolumn{4}{|l|}{ (1) Ratio of real revenues to real expenditures } \\
\hline (a) Imputing self-employed income & 0.927 & 1.012 & 0.853 \\
\hline (b) Imputing self-employed and pension income & 0.928 & 1.012 & 0.848 \\
\hline (c) Immigrants' consumption is $80 \%$ than natives' & 0.933 & 0.966 & 0.803 \\
\hline (d) Assigning capital taxation to long-term residents & 0.932 & 0.976 & 0.814 \\
\hline (e) Accounting for number of children in family benefits & 0.930 & 1.025 & 0.824 \\
\hline (f) Marginal cost (MC) scenario + imputing self-employed income & 0.918 & 1.129 & 0.919 \\
\hline (g) MC scenario + Imputing self-employed and pension income & 0.919 & 1.130 & 0.914 \\
\hline (h) MC scenario + Immigrants' consumption is $80 \%$ than natives' & 0.924 & 1.075 & 0.863 \\
\hline (i) MC scenario + assigning capital taxation to long-term residents & 0.923 & 1.087 & 0.876 \\
\hline (j) MC scenario + accounting for number of children in family benefits & 0.921 & 1.146 & 0.885 \\
\hline \multicolumn{4}{|l|}{ (2) Revenues/expenditures ratio, relative to natives } \\
\hline (a) Imputing self-employed income & 1.000 & 1.091 & 0.920 \\
\hline (b) Imputing self-employed and pension income & 1.000 & 1.091 & 0.915 \\
\hline (c) Immigrants' consumption is $80 \%$ than natives' & 1.000 & 1.035 & 0.861 \\
\hline (d) Assigning capital taxation to long-term residents & 1.000 & 1.047 & 0.874 \\
\hline (e) Accounting for number of children in family benefits & 1.000 & 1.103 & 0.887 \\
\hline (f) Marginal cost (MC) scenario + imputing self-employed income & 1.000 & 1.229 & 1.001 \\
\hline (g) MC scenario + Imputing self-employed and pension income & 1.000 & 1.230 & 0.995 \\
\hline (h) MC scenario + Immigrants' consumption is $80 \%$ than natives' & 1.000 & 1.163 & 0.934 \\
\hline (i) MC scenario + assigning capital taxation to long-term residents & 1.000 & 1.177 & 0.949 \\
\hline (j) MC scenario + accounting for number of children in family benefits & 1.000 & 1.245 & 0.961 \\
\hline
\end{tabular}

Notes. The Table reports, for natives, EEA and non-EEA immigrants, and cumulated over fiscal years 19952011: (1) the ratio of revenues contributed to expenditures received, (2) the revenues/expenditures ratio for the respective immigrant group relative to natives. Under each heading, we report results obtained when we allocate to immigrants the average cost of public goods (a-e) and (a) impute income of the self-employed, based on their sector of activity, (b) impute additionally state pension income to pension recipients, (c) assume that immigrants consume $80 \%$ than comparable natives, (d) assign all revenues from company and capital taxes to natives and immigrants in the UK for more than 10 years, (e) account for number of dependent children in apportioning social expenditures on family and children. In rows (f-j), we report results under the same assumptions but we allocate immigrants the marginal cost of public goods.

ally, in recent years, based on the ratio between immigrant groups and natives ( $R R E$, defined in (5), subsection 1.2.2, and shown in Figures $3 b$ and $4 b$ ), recent immigrants have made a far higher net fiscal contribution in each year since 2001 than natives.

One particularly interesting statistic is the difference between the first columns in Tables A5 and A6, which measures the reduction brought about by immigration in the costs that natives bear for fixed public goods. According to this statistic, the implicit savings from sharing the fiscal burden of these goods among a larger population are not only quite substantial but have been rising over time. For example, these 'implicit savings' for natives in expenditure on 'pure’ public goods totalled about £3.4 billion in 1995 (equivalent to $£ 4.7$ billion in 2011 prices) but amounted to a $£ 12$ billion saving in 2011. The cumulative implicit savings between 1995 and 2011 sum up to $£ 82$ billion. Moreover, when we consider the 'marginal' fiscal impact of immigration, the net fiscal contribution of EEA immigrants is positive in all years from 1996 to 2011 (except 2009, when it is zero), even in those years in which the native net fiscal contribution is negative. The relative fiscal contribution of non-EEA immigrants is very close to that of natives. 
Table 8

Robustness Checks: 2001-2011

\begin{tabular}{|c|c|c|c|c|}
\hline & Natives & $\begin{array}{l}\text { Recent } \\
\text { A10 }\end{array}$ & $\begin{array}{c}\text { Recent } \\
\text { other EEA }\end{array}$ & $\begin{array}{c}\text { Recent } \\
\text { non-EEA }\end{array}$ \\
\hline \multicolumn{5}{|l|}{ (1) Ratio of real revenues to real expenditures } \\
\hline (a) Imputing self-employed income & 0.896 & 1.107 & 1.493 & 0.953 \\
\hline (b) Imputing self-employed and pension income & 0.896 & 1.086 & 1.503 & 0.946 \\
\hline (c) Immigrants' consumption is $80 \%$ than natives' & 0.901 & 1.050 & 1.561 & 0.980 \\
\hline (d) Assigning capital taxation to long-term residents & 0.900 & 1.002 & 1.526 & 0.937 \\
\hline (e) Accounting for number of children in family benefits & 0.897 & 1.129 & 1.647 & 1.014 \\
\hline $\begin{array}{l}\text { (f) Marginal cost (MC) scenario + imputing } \\
\text { self-employed income }\end{array}$ & 0.887 & 1.301 & 1.765 & 1.059 \\
\hline $\begin{array}{l}\text { (g) MC scenario + Imputing self-employed and } \\
\text { pension income }\end{array}$ & 0.887 & 1.276 & 1.777 & 1.051 \\
\hline (h) MC scenario + Immigrants' consumption is $80 \%$ than natives' & 0.892 & 1.231 & 1.848 & 1.091 \\
\hline $\begin{array}{l}\text { (i) MC scenario + assigning capital taxation to } \\
\text { long-term residents }\end{array}$ & 0.891 & 1.170 & 1.805 & 1.040 \\
\hline $\begin{array}{l}\text { (j) MC scenario + accounting for number of children } \\
\text { in family benefits }\end{array}$ & 0.888 & 1.332 & 1.957 & 1.129 \\
\hline \multicolumn{5}{|l|}{ (2) Revenues/expenditures ratio, relative to natives } \\
\hline (a) Imputing self-employed income & 1.000 & 1.235 & 1.667 & 1.064 \\
\hline (b) Imputing self-employed and pension income & 1.000 & 1.212 & 1.677 & 1.055 \\
\hline (c) Immigrants' consumption is $80 \%$ than natives' & 1.000 & 1.166 & 1.733 & 1.088 \\
\hline (d) Assigning capital taxation to long-term residents & 1.000 & 1.113 & 1.696 & 1.041 \\
\hline (e) Accounting for number of children in family benefits & 1.000 & 1.259 & 1.836 & 1.131 \\
\hline $\begin{array}{l}\text { (f) Marginal cost (MC) scenario + imputing } \\
\text { self-employed income }\end{array}$ & 1.000 & 1.467 & 1.989 & 1.194 \\
\hline $\begin{array}{l}\text { (g) MC scenario + Imputing self-employed and } \\
\text { pension income }\end{array}$ & 1.000 & 1.438 & 2.002 & 1.184 \\
\hline $\begin{array}{l}\text { (h) MC scenario + Immigrants' consumption is } 80 \% \\
\text { than natives' }\end{array}$ & 1.000 & 1.380 & 2.072 & 1.223 \\
\hline $\begin{array}{l}\text { (i) MC scenario + assigning capital taxation to } \\
\text { long-term residents }\end{array}$ & 1.000 & 1.313 & 2.026 & 1.168 \\
\hline $\begin{array}{l}\text { (j) MC scenario + accounting for number of children } \\
\text { in family benefits }\end{array}$ & 1.000 & 1.500 & 2.203 & 1.271 \\
\hline
\end{tabular}

Notes. The Table reports for natives and recent immigrants (arrived since 2000), where we distinguish between A10, other EEA and non-EEA, cumulated over fiscal years 2001-11: (1) the ratio of revenues contributed to expenditures received, (2) the revenues/expenditures ratio for the respective immigrant group relative to natives. Under each heading, we report results obtained when we allocate to immigrants the average cost of public goods (a-e) and (a) impute income of the self-employed, based on their sector of activity, (b) impute additionally state pension income to pension recipients, (c) assume that immigrants consume $80 \%$ than comparable natives, (d) assign all revenues from company and capital taxes to natives and immigrants in the UK for more than 10 years, (e) account for number of dependent children in apportioning social expenditures on family and children. In rows $(\mathrm{f}-\mathrm{j})$, we report results under the same assumptions but we allocate immigrants the marginal cost of public goods.

\subsubsection{Immigrant education}

As discussed in subsection 1.1.1, we are probably underestimating immigrants' relative fiscal contribution by assigning to them the cost of educating their children and assigning to natives the benefit of these children later paying taxes. At the same time, we do not account for the savings to the native population of immigrants arriving in the UK after completing their education abroad, and thus, as recently stressed by Office for Budget Responsibility chairman Robert Chote, ${ }^{38}$ at a point in their lifetime

38 See http://www.bbc.com/news/uk-politics-25732868. 
when the discounted net value of their future net fiscal payments is positive. If the UK had to provide each immigrant domestically with the level of education acquired in the home country (and used productively in the UK), those costs would be substantial.

To assess the magnitude of savings, therefore, we compute these figures using information on immigrants' educational attainments (based on LFS data) and the 2011 cost per student of a year of primary, secondary and tertiary education (based on information from the Department for Education and the Higher Education Statistics Agency) ${ }^{39}$ For each immigrant, we compute the number of years of primary, secondary and tertiary education brought to the UK on arrival. We then compute the amount this education would have cost the UK by multiplying the number of years of each education level acquired abroad by its cost and dividing this amount by the number of potential working age years available to the worker after education completion. This calculation gives an annuity of each worker's education cost per year. Based on these numbers, we can then compute the total annual cost that an equivalently educated number of UK-born workers would have cost the UK taxpayer.

Again however, we recognise that the above savings may be an overestimate: immigrants often downgrade in the UK labour market being employed in occupations for which they are formally overqualified, especially during the first years after arrival, and equivalent native workers would require less education to do the same job. We, therefore, also compute an alternative scenario in which we impute for each immigrant the average years of education of natives in the same occupation (based on 3 digit occupational codes in SOC 2000 and 2010) and then compute the cost of acquiring that level, rather than the immigrant's actual level, of education.

We display the results of these calculations in the bottom two rows of each panel of Table 5. These are the implicit savings to the UK taxpayer of immigrants obtaining their education abroad in each of the two scenarios discussed above. For the population of immigrants living in the UK between 1995 and 2011, the cumulated annual savings for all EEA immigrants employed in the UK for a level of education equivalent to that of British natives employed in the same occupations where immigrants work totals more than $£ 14$ billion, more than three times the amount of the net fiscal contributions EEA immigrants made directly to public finances. The equivalent number for non-EEA immigrants amounts to $£ 35.2$ billion. If we considered immigrants' actual level of education, the implicit savings would be even higher, as shown in the bottom row of panel $(a)$.

Our estimates for recent immigrants are reported in the two bottom rows of panel (b). These indicate that the annuities of the cost of education of recent A10 immigrants in relation to the work performed in the UK would have amounted over the 2001-11 period to about $£ 4.3$ billion. If we considered the cost of their actual education level, this figure would be about $£ 6.2$ billion. The respective numbers for immigrants from the other EEA countries are $£ 2.5$ and $£ 3.2$ billion, respectively, and for recent nonEEA immigrants, $£ 11.2$ and $£ 14.6$ billion respectively. Overall, these figures point to substantial savings to the taxpayer from immigrants arriving in the UK with their

\footnotetext{
39 We thank Anna Vignoles for pointing us to the appropriate data. See the online Appendix B, for a more detailed description of the procedure and the data sources.
} 
education paid for by their home countries - an aspect ignored in our previous calculations of the net fiscal benefit of immigration.

\section{Robustness Checks}

As previously explained, the estimates in Table 6 are computed for a baseline scenario that

(i) allocates the cost of educating immigrants' children to immigrants but then accredits the fiscal contribution of their children to natives;

(ii) allocates to immigrants the average cost of all non-congestible public goods; and

(iii) ignores the savings in tax payments to UK natives from immigrants' educational expenses being paid by the source countries.

Each of these omissions is likely to be substantial, as formally demonstrated for (ii) and (iii). Hence, the figures we report in the Tables are likely to be conservative from the viewpoint of the migrant. In addition to assumptions (i)-(iii), the baseline scenario presented in the Table is based on a set of additional assumptions (discussed above) made when computing the apportioning coefficients. Although we believe that these latter are plausible, we now provide additional results using modified assumptions.

Specifically, we consider the following modifications:

(a) we impute self-employed income based on the sector of activity of the selfemployed;

(b) we also impute pension income to all pension claimants;

(c) we assume that immigrant consumption is $80 \%$ that of natives with a comparable household income, which results in lower payments of indirect taxes;

(d) we assign company revenues and capital taxes, including business rates, only to natives and immigrants who have spent more than 10 years in the UK; and

(e) we account for the number of dependent children in the household in the apportionment of family benefits.

The revenues/expenditures ratio ( $R E$ in (4)) for each population group and the revenues/expenditures ratio of immigrants relative to natives $(R R E$ in (5)) estimated under these alternative conjectures are displayed in the respective rows of Table 7 , for all the resident population between 1995 and 2011, and Table 8, for recent immigrants between 2001 and 2011. ${ }^{40}$ In rows $(f-j)$ we replicate all the scenarios under $(a-e)$ for the marginal effect scenario.

Although the estimates of immigrants' and natives' contributions fluctuate across the different scenarios, our qualitative results remain unaffected: the fiscal contributions of EEA immigrants and recent immigrants from all areas of origin are higher, in relative terms, than those of natives in all scenarios. For recent A10 immigrants,

\footnotetext{
${ }^{40}$ We report the overall net fiscal contribution expressed in millions of $£ 2011$ equivalent in Appendix Table A7.
} 
the $R R E$ ratio ranges between 1.113 (scenario $(d)$ ) and 1.5 (scenario $(j)$ ), compared with baseline estimates of 1.252 in the 'average effect scenario' and 1.487 in the 'marginal effect scenario'. The same ratio ranges between 1.667 and 2.203 for the other recent EEA immigrants and between 1.041 and 1.271 for recent non-EEA immigrants. For these latter groups, the $R R E$ ratios in our baseline estimates were 1.833 and 1.154, respectively, in the 'average effect scenario', and 2.196 and 1.302 in the 'marginal effect scenario'. Even in the most restrictive scenarios such as scenario $(d)$, in which we assume that recent immigrants do not contribute at all to revenues from company and capital taxes and business rates, EEA immigrants who arrived since 2000, both from the A10 and other EEA countries, are making overall positive fiscal contributions.

\section{Conclusions}

Although the fiscal contribution of immigrants has emerged as a key issue of concern in the public debate on immigration, very little evidence is yet available that allows assessment of how much immigrants take out of and contribute to the public purse. This study attempts to fill this void by suggesting a simple methodology that answers the focal policy questions by identifying the conceptual and methodological difficulties these issues present and offering implementable solutions. We then apply this methodology specifically to the UK, a country in which this debate has been particularly fierce over recent years.

We first present analysis of the immigrant population resident in the UK in every year since 1995 . We point out that - as we do not follow arrival cohorts - such analysis ignores contributions made of immigrants of the same cohorts who have returned, and is sensitive to the pattern of past arrivals. Our results suggest a clearly positive contribution by European immigrants in terms of what they pay into the fiscal system versus what they receive in benefits and transfers. Immigrants from non-EEA countries, on the other hand, contribute less than they receive; however, this outcome is similar, albeit larger in magnitude, to natives, who also make a negative net contribution over the same period. This finding may partly be explained by the larger number of children non-EEA immigrants have over the period considered, whose cost we assign to immigrants while assigning these children's contributions after entering the labour market to natives. Yet this strategy, necessitated by a lack of information in our data set on the foreign born status of immigrants' parents, is likely to overestimate (rather than underestimate) the relative cost of immigrants in all our computations.

With respect to the recently arrived immigrant populations, those who came to the UK after 1999, our analysis suggests that - rather than being a drain on the UK's fiscal system - they have made substantial net contributions to its public finances, a reality that contrasts starkly with the view often maintained in public debate. These findings for recent immigrants change little even when our computations of net contributions calculate the apportioning coefficients under different assumptions. This conclusion is further supported by the probability of these immigrants' receiving tax credits and benefits being lower than that of natives.

We thus conclude that the recent wave of immigrants, those who have arrived in the UK since 2000 and driven the stark increase in the UK's foreign born population, 
have contributed far more in taxes than they have received in benefits. Moreover, by sharing the cost of fixed public expenditures (which account for more than $14 \%$ of total public expenditure), they have reduced the financial burden of these fixed public obligations for natives. In fact, we estimate considerable implicit savings on these expenditures - just short of $£ 24$ billion between 2001 and 2011. This figure is even more striking considering that our calculations do not take into account the savings to the UK taxpayers of immigrants arriving with their education paid for by taxpayers in other countries. Such savings are themselves substantial: if allocated as an annuity to immigrants according to the education levels of natives in the same occupations, they amount to more than $£ 18$ billion for recent immigrants in the 2001-11 period.

These findings place the UK in a far more favourable position than its European neighbours. For instance, Bratsberg et al. (2014) show that in Norway, immigrants tend to assimilate out of the labour market and display increasingly higher rates of reliance on the welfare state than natives over their lifecycle. Our findings are, however, broadly in line with a recent OECD study (Liebig and Mo, 2013) that emphasises immigrants' positive contributions to the UK fiscal system compared to the situation in other countries. One unique aspect of our work is that by covering so many years, we avoid the caveat that the strong cyclicality of immigrations' fiscal effects may generate results that hold only for the short term. Our findings are, therefore, likely to present a far more robust long-term picture.

Some may argue, of course, that part of our positive picture of recent UK immigrants may be related to their favourable age structure. Although we cannot compute counterfactuals for the net fiscal contributions of recent immigrants if they had the same age structure as natives, our results for tax credits and benefits receipt (for which we do compute such counterfactuals) remain favourable for immigrants relative to natives even assuming the same age structure for the two groups. Moreover, while ageing of the immigrant population that arrived since 2000 may lead in the longer run to an increase in benefit receipt, such an increase may be counteracted by two factors. First, it is likely that many of these immigrants will return migrate, thereby spending their later and less productive years in their home countries (Dustmann and Weiss, 2007). Second, a large fraction of these recent immigrants are at the beginning of their careers - and possibly underemployed for lack of complementary skills like language and thus far from reaching their full economic potential (Dustmann et al., 2013). Hence, although their net contributions may decrease in later years because of demographic changes, given their more favourable educational distribution, the contributions of those who decide to stay in the UK will probably increase through individual career development. Indeed, recent immigrants' returns to an additional year of labour market experience are 1.2 percentage points higher than those for natives (see Section 3).

In addition, our investigation of recent immigration to the UK reveals that, even though one-third of UK immigration is through movement within the EEA and cannot be regulated, the UK is still - and possibly even more so than in previous years (Dustmann and Fabbri, 2005) - able to attract highly educated and skilled immigrants. This surprisingly positive trend, which continued even throughout the last recession, 
distinguishes the UK sharply from other European and non-European countries. ${ }^{41}$ This ability to attract highly skilled immigrants - even from within the EEA, where no restrictions can be imposed - is a strong and important feature of the UK economy.

Our analysis also pinpoints questions that are underexplored and need to be addressed in future research. One such issue is the remigration of immigrants. For instance, if immigrants tend to return to their country of origin after reaching an individual career peak, it would bring additional relief to the UK's fiscal system. Another important question is whether it is immigrants who perform very strongly or those whose contributions fall below average that are the most likely to remain. This important issue, although it presents several empirical challenges (Dustmann and Gorlach, 2014), opens an exciting new avenue for future research.

\section{Appendix A. Construction of the Apportioning Coefficients}

This Appendix details the procedure and data sources used to construct the apportioning coefficients for each item of government revenues or expenditures outlined in subsection 1.2.3.

\section{A.1. Revenues}

(1) Income tax and National Insurance Contribution payments. We estimate each group's share of total payments by applying year-specific NIC and income tax rates and allowances to individual wages based on the LFS variable grsswk (gross weekly wages). We aggregate weekly wages into annual salaries, including wages from a second job (from the LFS variable grsswk2). Next, for each individual, we compute the probable amount of pension payments in two steps: first, we collect data on the probability that the individual contributes into a private pension scheme and on the average rate of pension payments. Second, we obtain estimates of pension payments by applying the pension payment rate, multiplied by the probability of contributing to a pension plan, to individual gross earnings. We obtain the year-specific proportion of individuals with private pensions by age, sex, work pattern and income from Table 6.6, 'Current pension scheme membership by sex and usual gross weekly earnings', of the annual ONS reports on the General Lifestyle Survey (since 2008) and the General Household Survey (for earlier years). ${ }^{42}$ We set the rate of pension payments for everyone at the year-specific national average for private sector employees, calculated from the Occupational Pension Scheme Survey (OPSS) as the weighted average of contribution rates to DB and DC pension plans (reported in the Occupational Pension Scheme Survey Annual Report). ${ }^{43}$ We then subtract the estimated pension payments and the

\footnotetext{
41 For example, in a recent paper, Dustmann and Frattini (2013) show that the UK is among the Western European countries with the highest share of tertiary educated immigrants after only Ireland and Norway. Not only is the UK in a position to attract better educated immigrants overall, it also attracts better educated immigrants from the same emigration countries as its European neighbours. For example, in 2007, 26\% of Polish immigrants in the UK had a tertiary education compared to only $11 \%$ in Germany (Dustmann et al., 2015).

42 Because 2010 is the latest available year, we use 2010 figures for 2011. Likewise, because the General Household Survey was not administered in either 1997/8, when it was reviewed, or in 1999/2000, when it was redeveloped, meaning that data for those years are missing, we use 1998 figures for 1999 and for all earlier years also.

${ }^{43}$ The average contribution rates in DB and DC schemes and the total number of active members (employees) within each type of pension scheme are reported in Table 3.2 and Table 2.6, respectively, of the OPSS Report. We take an annual average of contributions to DB and DC schemes, weighting each schemespecific contribution rate (from Table 3.2) by the share of employees in each type of scheme (from Table 2.6). Prior to becoming an annual survey, the OPSS was conducted every four years. Hence, data on average contribution rates are not available for every year between 1993 and 2004 . We, therefore, use 2000 data for all years before 2000, as well as for 2001 and 2002; 2004 data for 2003; and 2010 data for 2011.
} 
individual year-specific personal allowance from the gross annual earnings to obtain a measure of taxable income and compute personal income taxes paid by applying the appropriate yearspecific rates of income tax to this measure of taxable earnings. ${ }^{44}$

For National Insurance Contribution (NIC) payments, we apply the appropriate year-specific rates to gross weekly wages in the first and second job and include payments paid by both the employer and the employee. Then, for income tax and NIC separately, we sum the total estimated payments within the sample, and estimate the share of each sub-population group (natives, EEA immigrants and non-EEA immigrants) in total payments. We use these shares to apportion the aggregate tax data in each fiscal year across groups.

Because the LFS has no information on self-employment income, in our central scenario, we apportion the overall revenues from income taxes and NIC using the share of payments estimated for the sample of employees only. As a robustness check, however, we also impute selfemployment income based on sector of activity and use it to compute the apportioning coefficients. Mean self-employment income by sector of activity is constructed based on data from the Survey of Personal Incomes (SPI) and from the LFS. We obtain data on the total amount of self-employed income by sector from the SPI, an annual sample survey of HM Revenue and Customs records for individuals who could be liable for UK income tax, as provided by the ONS in Table 3.9 'Self-employment income assessable to tax' of 'Personal Income By Tax Year'. Then, from the LFS data, we compute the number of self-employed workers in each sector and use this information to compute mean self-employed income by sector in each year. We collected data on self-employment income assessable to tax for fiscal years 1999-2007 and 2009-11. For fiscal years until 2007 sectors are defined based on SIC 92, whereas for fiscal years 2009-11 sectors are defined based on SIC 07. We impute 1999 income for years 1995-8, 2007 income for 2008 Quarters 2-4 and 2009 income to Q1 2009. In all cases, we assume real income has not changed but allow for variations in nominal income discounting base-years values by the CPI.

The LFS does not have information also on the amount of social transfers received. In particular, although it contains information on whether individuals receive pension payments, it does not record the amount of pensions received. Since the Basic State Pension is a taxable transfer, in a robustness check we impute state pension income to pension claimants, based on historic rates provided as an annex to Bozio et al. (2010). ${ }^{45}$ Since we do not know how many years individuals paid NIC for and what category of pension they claim, and thus we cannot determine precisely the amount of pensions received, we assume that they all claim the full amount of Category A pension. We then compute the amount of income tax paid accounting for imputed pension income and use these payments to estimate the apportioning coefficients.

(2) VAT and excise duties. We estimate each group's share of payments for each of these taxes using a multi-step procedure. First, for each indirect tax and based on the ONS publication 'The Effect of Taxes and Benefits on Household Income', ${ }^{46}$ we compute the ratio of tax payments to original income for households in each decile of the distribution of households' disposable income. We thus obtain the 'effective rate' individuals in different parts of the income distribution should pay on their gross earnings in order to achieve the amount of payments made on average by individuals in that income decile. Then we sum over all individual disposable earnings (i.e. gross earnings minus income tax and NIC payments) within each

\footnotetext{
${ }^{44}$ For rate guidance and information on income tax and NI structure see http://www.hmrc.gov.uk/stats/ income_tax/index.htm. For NIC rates and allowances, see http://www.hmrc.gov.uk/rates/nic.htm and for NIC guidance, see www.hmrc.gov.uk/nic/background-nic.htm.

45 Available at http://www.ifs.org.uk/bns/bn105figs.xls.

46 Available at http://www.ons.gov.uk/ons/rel/household-income/the-effects-of-taxes-and-benefits-onhousehold-income/historical-data/sum-historical-tables.html. In each fiscal year, we use information from Table 24: 'Average incomes, taxes and benefits by decile groups of ALL households (ranked by UNADJUSTED disposable income)'.
} 
household in the LFS and determine the household position in the sample distribution of disposable earnings. Since we have no information on other type of incomes in the LFS we assume that households are in the same decile of the distribution of disposable income as of disposable earnings. Finally, we apply the estimated decile-specific 'effective rate' to gross individual earnings from the LFS. We can then compute apportioning shares for each indirect tax by summing total estimated payments within the sample and estimating the share of each sub-population group (natives, EEA immigrants, non-EEA immigrants) in total payments.

The implicit assumption with this strategy is that immigrants and natives with similar incomes have the same consumption patterns. However, immigrants, especially those who have arrived more recently, may have lower consumption than natives. For this reason, we also compute an alternative set of apportioning coefficients where we assume that the consumption of recent immigrants (those arrived since 2000) is only $80 \%$ that of natives with a similar income. In practice, under this assumption we apply the 'effective tax rate' to $80 \%$ of immigrants' income.

As discussed in (1), the LFS does not include self-employment income and income originating from benefits and transfers. The lack of this information may generate two sources of bias in estimating payments of VAT and other indirect taxes. First, a household that receives part of its income from self-employment or welfare benefits will be ranked lower than a household with the same total income, but coming entirely from labour earnings. Since the 'effective rates' we compute for indirect taxes are higher for the bottom income deciles, this will bias upwards the estimated 'effective rate' of households for which self-employment income and welfare transfers are a larger share of total income. Second, for these households we observe a total income which is lower than their actual income and can thus apply the 'effective rate' to just a fraction of their overall income, which will bias downwards the estimated tax payments. Overall, therefore, there are two potential sources of bias, going in opposite directions and thus partly cancelling each other out. To try and correct for these biases, as described in (1) we also conduct sensitivity checks where we impute self-employed income and where we impute pension transfers. In the latter case, we compute the 'effective rate' as the ratio of tax payments to the sum of original income and state pension income. We then proceed as in our benchmark case.

(3) Company and capital taxes. The allocation of corporate taxation raises complicated questions of incidence which are the subject of several studies in the specialised literature. The actual burden of corporate taxation does not fall on business owners only but falls also upon workers and customers. However, there is no consensus on the exact allocation of this burden. In our central scenario, we apportion these tax payments, net of the percentage likely to be paid by foreign shareholders which ranges in the fiscal years considered between $16 \%$ and $40 \%,{ }^{47}$ on a per capita basis among the adult population. This allocation criterion can be interpreted in two alternative ways. One can think of this choice as capturing that the real burden of corporate taxes may fall ultimately on consumers, thus it has to be shared on a per capita basis. Alternatively, this choice can be interpreted as the consequence of an implicit assumption that share ownership is shared equally among the whole resident population.

As a sensitivity check on our results, we also alternatively compute apportioning shares under the (possibly extreme) assumption that the burden of company and capital taxes falls only on owners and that ownership is equally shared among long-term residents in the UK (i.e. natives and immigrants who have been in the UK for more than 10 years). In this alternative scenario, we therefore apportion company and capital tax payments, net of the share likely paid by foreign shareholders, proportionately to the population who has been in the UK for more than 10 years (i.e. natives and long-term immigrants).

(4) Council tax. The council tax is levied on domestic residences by individual local authorities dependent on the capital value of the property. Council tax rates vary substantially across local

\footnotetext{
47 The share of foreign ownership in UK companies is available from the annual ONS 'Share Ownership'
} report. 
authorities and do not reflect the average value of housing between local authorities. While within each local authority higher value houses are subject to a higher tax, it is not true that areas with the highest average housing value have higher council taxes. For instance, the band D tax in the wealthy London council of Westminster is $£ 676.74$ in $2013 / 14$, while a band D property in the poorer Hackney council is charged a council tax of $£ 1,301.45$. Therefore, in the absence of precise information on the local authority and on the type of housing where immigrants and natives live, we apportion council tax payments based on the number of immigrant and native households. Because we have no detailed information on individual housing value or local tax levels, we abstract from such differences and simply estimate each group's share of council taxes as proportional to the number of households in the group. Allocation based on number of households, rather than individuals, accounts for potentially different household sizes across population groups.

(5) Business rates. We treat business rates payments similarly to company and capital tax payments. Hence in our central scenario, we apportion them proportionately to the adult population, while in a robustness check we allocate them to native and long-term immigrants (those in the UK for more than 10 years) only.

(6) Gross operating surplus and rents and interests and dividends. We apportion government's gross operating surplus and rents and interests and dividends proportionately to the share of each group in the adult $(16+)$ population in our central 'average effect' scenario. However, in the 'marginal effect' scenario we attribute these revenues entirely to natives, thus implicitly assuming that they are the result of government operations undertaken before immigrants' arrival.

(7) Inheritance tax. We use house ownership (from the LFS) as a proxy for asset ownership and apportion inheritance tax proportionately to the share of natives and immigrants above the age of 70 in the house-owner population.

(8) Other. All remaining tax payments including landfill tax, climate change levy, aggregates levy, other taxes and royalties, and other receipts, are apportioned according to the share of each group in the adult $(16+)$ population.

\section{A.2. Expenditures}

(I) Pure public goods and services. This category includes all public goods and services that are typically non-rival in consumption. In our central scenario ('Average effect scenario'), we apportion the cost of providing these goods proportionately to the share of each group in the adult $(16+)$ population. In our second scenario ('Marginal effect scenario'), we attribute these expenditures entirely to natives.

(II) Congestible public goods and services. We apportion the cost of providing these goods according to each group's share in the adult $(16+)$ population in all scenarios.

(III) Medical and other health services. We estimate the proportion of health services expenditure attributable to each group based on the group's age structure. We treat the share of health costs by age group as time invariant. Specifically, we use the 2004 distribution of health costs by age group, as reported in Figure 6.2 of the Department for Health Departmental Report 2006. For each year, we first compute the estimated amount spent for health services on each age group, we then apportion the costs of each age group proportionately to the share of immigrants and natives in each age band. We thus make the implicit assumption that immigrants and natives with the same age make the same use of health services.

(IV) Education. For compulsory education, we estimate each group's apportioning coefficient based on the share of children in the relevant age bracket for each school level $(0-4$ for preprimary, 5-15 for primary and secondary). For post-secondary education, we compute the share of the school population for each group using direct information from the LFS on type of school attended by those still in the education system. This choice rests on the implicit assumption that the average cost of educating children of immigrants and natives is the same. 
While one can imagine that the marginal cost of educating an immigrant child may be lower (because schools have already been built and teachers already hired) or higher (because they may have, for instance, a language problems and thus require extra attention relative to natives), we could not recover any estimates of differences in relative education costs. For this reason, we simply assume that the average cost of their education is the same.

(V) Social protection. Expenditures for social protection include expenditure for sickness and disability, old age, family and children, unemployment, housing and social exclusion. Since about $85 \%$ of these expenditures are allocated in terms of cash benefits, we use LFS information on the receipt of different types of benefits and compute for each group the share among the total recipients of each type of benefit. Specifically, we use the LFS variables tpben09, tpbn03, tpbn01 and typben which report, in different years, the type of benefit claimed by welfare claimants. Because we have no information on the amount of benefits received, in general we implicitly assume that every recipient receives the same amount. However, the average amount of housing benefits receipts varies substantially across regions. Therefore, in the apportionment of expenditures for 'social protection: housing', we account for such regional differences in the regional amount of average claims and for differences in the regional distribution of immigrant and native claimants. Specifically, we first extract from the DWP's Stat-Xplore tabulation tool the number of housing benefit claimants and the mean of weekly award amount for December and January of each fiscal year 2008-11 (i.e. starting in December 2008 and until January 2012), by Government Office Region (GOR).$^{48}$ We then compute the regional share of national payments in each fiscal year and calculate the average across fiscal years. We use these average shares to allocate total housing expenditure for 'social protection: housing' between regions in all fiscal years 1995-2011. ${ }^{49}$ We then apportion the computed regional expenditures to different population groups according to the proportion of immigrants and natives among housing benefit recipients in each region. Thus, we implicitly assume that within the same region everyone receives the same amount.

Expenditures for 'social protection: family and children' include a variety of benefits, such as: paternity pay, child maintenance and enforcement commission, income support, maternity allowance, sure start maternity grants and child benefit. Since we do not have enough information to estimate the amount of each type of benefit received by individuals in the LFS, in our baseline scenario we just apportion social expenditure for family and children proportionately to the share of income support or family-related benefit recipients, assuming that everyone receives the same amount. However, since the amount of child benefits depends on the number of children (with a higher rate for the eldest or only child and a lower rate for subsequent children), in a robustness check we alternatively allocate the whole social expenditure for family and children proportionately to the number of dependent children among income support or family-related benefit recipients.

(VI) Prisons and law courts. We use information on the nationality of prison inmates from the Ministry of Justice's Offender Management Caseload Statistics and apportion prison costs proportionately to the size of each group in the prison population. Note that in this case we thus define immigrant status based on nationality, not on country of birth. ${ }^{50}$

(VII) Housing development. Housing development comprises of expenditures for social and local authority housing. We estimate each group's share of total costs based on its share of social housing tenants reported in the LFS.

\footnotetext{
48 The DWP's Stat-Xplore tabulation tool is available at: https://www.gov.uk/government/collections/ dwp-statistics-tabulation-tool.

${ }^{49}$ Note that we have no data on housing benefits in Northern Ireland, therefore we just allocate the national expenditures across the 11 GORs of England, Scotland and Wales.

50 The Offender Management Caseload Statistics is available at: https://www.gov.uk/government/ publications/offender-management-statistics-quarterly-2.
} 
(VIII) Police services. We distinguish between 'immigration-related police services' and 'other police services'. We apportion expenditures for the former only to immigrants, proportionately to the share of each group in the total immigrant population. Since most other police services are equally used by immigrants and natives, we attribute expenditure for the latter set of services on a per capita basis among the whole population.

\section{Table A1}

Expenditures Allocation Criteria

\begin{tabular}{|c|c|c|c|}
\hline & $\begin{array}{l}\% \text { of } \\
\text { total }\end{array}$ & Main apportioning criterion & Alternatives \\
\hline 'Pure' public goods & 16.5 & Share of $16+$ population (average cost) & \\
\hline 'Congestible' public goods & 14.4 & $\begin{array}{l}\text { Share of } 16+\text { population (average cost)/ } \\
\text { All to natives (marginal cost) }\end{array}$ & \\
\hline $\begin{array}{l}\text { Health costs (except medical } \\
\text { research) }\end{array}$ & 16.9 & $\begin{array}{l}\text { Share of population in age group, and } \\
\text { share of total health costs of age group }\end{array}$ & \\
\hline $\begin{array}{l}\text { Compulsory education: } \\
\text { pre-primary }\end{array}$ & 0.7 & Share of $[0,4]$ children population & \\
\hline $\begin{array}{l}\text { Compulsory education: primary } \\
\text { and secondary }\end{array}$ & 8.4 & Share of $[5,15]$ years old population & \\
\hline Further education & 1.0 & Share of population in further education & \\
\hline Higher education & 1.9 & Share of population in higher education & \\
\hline $\begin{array}{l}\text { Social protection: Sickness and } \\
\text { disability }\end{array}$ & 4.8 & $\begin{array}{l}\text { Share of sickness and disability benefit } \\
\text { claimants }\end{array}$ & \\
\hline Social protection: Pensions & 13.2 & Share of pension claimants & \\
\hline $\begin{array}{l}\text { Social protection: Family and } \\
\text { children }\end{array}$ & 7.4 & $\begin{array}{l}\text { Share of income support or family- } \\
\text { related benefits claimants }\end{array}$ & $\begin{array}{l}\text { Share of dep. child. } \\
\text { among inc.supp. } \\
\text { or family-rel. } \\
\text { benefits claimants }\end{array}$ \\
\hline Social protection: Unemployment & 1.0 & $\begin{array}{l}\text { Share of unemployment benefits } \\
\text { recipients }\end{array}$ & \\
\hline $\begin{array}{l}\text { Social protection: Housing } \\
\text { benefits }\end{array}$ & 3.5 & $\begin{array}{l}\text { Share of region-specific housing benefits } \\
\text { recipients }\end{array}$ & \\
\hline $\begin{array}{l}\text { Social protection: Personal social } \\
\text { services }\end{array}$ & 4.5 & $\begin{array}{l}\text { Average of share of sickness and disability } \\
\text { benefits recipients, pension claimants, } \\
\text { income support or family-related } \\
\text { benefits recipients }\end{array}$ & \\
\hline Law courts and prisons & 1.9 & Share of prison population & \\
\hline Housing development & 1.1 & $\begin{array}{l}\text { Share of social housing tenants } \\
\text { population }\end{array}$ & \\
\hline $\begin{array}{l}\text { Immigration and citizenship } \\
\text { police services }\end{array}$ & 0.3 & Share of immigrant population & \\
\hline Other police services & 2.8 & Share of population & \\
\hline EU transactions & -0.2 & Share of population & \\
\hline
\end{tabular}

Notes. Column 1 reports the categories in which we have grouped public expenditure items from Table 5.2 of PESA 2012 (years 2007-11), Table 5.2 of PESA 2009 (years 2003-6), Table 3.6 of PESA 2004 (years 19982002) and Table 4.5 of PESA 1999-2000 (years 1995-7). Column 2 reports the share (in percent) of total public expenditure accounted for by each category, pooling all years 1995-2011. Column 3 summarises the criteria followed in the construction of apportioning coefficients for each group. Column 4 summarises the alternative criteria which we use in the robustness checks. 
Table A2

Receipts Allocation Criteria

\begin{tabular}{|c|c|c|c|}
\hline & $\begin{array}{l}\% \text { of } \\
\text { total }\end{array}$ & Baseline & Alternatives \\
\hline $\begin{array}{l}\text { Income tax and } \\
\text { National Insurance }\end{array}$ & 44.7 & $\begin{array}{l}\text { Share of total payments: actual tax and } \\
\text { NI rates applied to LFS earnings }\end{array}$ & $\begin{array}{l}\text { Same as baseline, but imputing } \\
\text { self-employment and pension } \\
\text { income }\end{array}$ \\
\hline $\begin{array}{l}\text { VAT and other } \\
\text { indirect taxes }\end{array}$ & 28 & $\begin{array}{l}\text { Share of total payments: effective rates by } \\
\text { household income decile from ONS } \\
\text { 'Effects of taxes and benefits on } \\
\text { household income', applied to LFS } \\
\text { earnings. }\end{array}$ & $\begin{array}{l}\text { Same as baseline, but imputing } \\
\text { self-employment and pension } \\
\text { income }\end{array}$ \\
\hline $\begin{array}{l}\text { Company and } \\
\text { capital taxes }\end{array}$ & 9.3 & $\begin{array}{l}\text { Share of adult population, net of foreign } \\
\text { owned share from ONS 'Share } \\
\text { ownership' }\end{array}$ & $\begin{array}{l}\text { Share of longterm residents } \\
\text { (>10 years), net of foreign } \\
\text { owned share from ONS 'Share } \\
\text { ownership' }\end{array}$ \\
\hline Council tax & 4.2 & Share of total households & \\
\hline Business rates & 4.3 & Share of adult population & $\begin{array}{l}\text { Share of longterm residents, net } \\
\text { of foreign owned share from } \\
\text { ONS 'Share ownership' }\end{array}$ \\
\hline $\begin{array}{l}\text { Gross operating } \\
\text { surplus and rents }\end{array}$ & 5 & $\begin{array}{l}\text { Share of adult population/All to natives } \\
\text { (marginal contribution) }\end{array}$ & \\
\hline Inheritance tax & 0.6 & $\begin{array}{l}\text { Share of houseowners population } \\
\text { age } 70+\end{array}$ & \\
\hline Income tax credits & -0.8 & Share of dependent children population & \\
\hline Other & 4.7 & Share of adult population & \\
\hline
\end{tabular}

Notes. Column 1 reports the categories in which we have grouped the items in Table C4 of the HM Treasury's Public Sector Finances Databank. Column 2 reports the share of total government receipts accounted for by each revenue source, pooling over all years 1995-2011. Column 3 summarises the criteria followed in the construction of apportioning coefficients for each group. Column 4 summarises the alternative criteria which we use in the robustness checks.

Table A3

List of Government Expenditures by Sub-Function (UN COFOG) and Grouping

\begin{tabular}{l}
\hline \hline Expenditure item \\
1.1 Executive and legislative organs, financial and \\
fiscal affairs, external affairs \\
1.2 Foreign economic aid \\
1.3 General services \\
1.4 Basic research \\
1.5 R\&D general public services \\
1.6 General public services n.e.c. \\
1.7 Public sector debt interest \\
2.1 Military defence \\
2.2 Civil defence \\
2.3 Foreign military aid \\
2.4 R\&D defence \\
2.5 Defence n.e.c \\
Health research \\
3.2 Fire-protection services \\
3.5 R\&D public order and safety \\
3.6 Public order and safety n.e.c. \\
4.1 General economic, commercial and labour affairs \\
4.2 Agriculture, forestry, fishing and hunting \\
4.3 Fuel and energy
\end{tabular}

(C) 2014 Royal Economic Society. 
Table A3

(Continued)

\author{
Expenditure item \\ 4.4 Mining, manufacturing and construction \\ 4.5 Transport \\ 4.6 Communication \\ 4.7 Other industries \\ 4.8 R\&D economic affairs \\ 4.9 Economic affairs n.e.c \\ 5.1 Waste management \\ 5.2 Waste water management \\ 5.3 Pollution abatement \\ 5.4 Protection of biodiversity and landscape \\ 5.5 R\&D environment protection \\ 5.6 Environment protection n.e.c \\ 6.2 Community development \\ 6.3 Water supply \\ 6.4 Street lighting \\ 6.5 R\&D housing and community amenities \\ 6.6 Housing and community amenities n.e.c \\ 8.1 Recreational and sporting services \\ 8.2 Cultural services \\ 8.3 Broadcasting and publishing services \\ 8.4 Religious and other community services \\ 8.5 R\&D recreation, culture and religion \\ 8.6 Recreation, culture and religion n.e.c \\ 9.5 Education not definable by level \\ 9.6 Subsidiary services to education \\ 9.7 R\&D education \\ 9.8 Education n.e.c \\ $10.8 \mathrm{R} \& \mathrm{D}$ social protection \\ 10.9 Social protection n.e.c. \\ 3.3 Law courts \\ 3.4 Prisons \\ 6.1 Housing development
}

Medical services

Central and other health services

9.1 Pre-primary and primary education: under fives

9.1 Pre-primary and primary education: primary education 9.2 Secondary education

9.3 Post-secondary non-tertiary education

9.4 Tertiary education

3.1 Police services: Immigration and citizenship

3.1 Police services: other police services

10.1 Sickness and disability: incapacity, disability and injury benefits

10.2 Old age: pensions

10.3 Survivors

10.4 Family and children: family benefits, income support and tax credits

10.7 Social exclusion n.e.c: family benefits, income support and tax credits
'Congestible' public goods

Law courts and prisons

Housing development

Health costs (except medical research)

Compulsory education: pre-primary

Compulsory education: primary and secondary Further education

Higher education

Immigration and citizenship police services

Other police services

SP: Sickness and disability

SP: pensions

SP: Family and children 
Table A3

(Continued)

\begin{tabular}{|c|c|}
\hline Expenditure item & Expenditure group \\
\hline $\begin{array}{l}\text { 10.5 Unemployment: other unemployment } \\
\text { 10.6 Housing }\end{array}$ & $\begin{array}{l}\text { SP: Unemployment } \\
\text { SP: Housing benefits }\end{array}$ \\
\hline $\begin{array}{l}\text { 10.1 Sickness and disability: personal social services } \\
\text { 10.2 Old age: personal social services } \\
\text { 10.4 Family and children: personal social services } \\
\text { 10.5 Unemployment: personal social services } \\
\text { 10.7 Social exclusion n.e.c: personal social services }\end{array}$ & SP: Personal social services \\
\hline Total EU transactions & EU transactions \\
\hline
\end{tabular}

Note. The Table reports the list of government expenditures by function from the UN COFOG classification, adopted in PESA issues after 2007 and the categories in which we have grouped them in our analysis.

Table A4

List of Government Receipts and Grouping

\begin{tabular}{|c|c|}
\hline Revenue source & Grouping \\
\hline $\begin{array}{l}\text { Income tax revenue } \\
\text { NICs payments }\end{array}$ & Income tax and National Insurance \\
\hline Income tax credits & Income tax credits \\
\hline $\begin{array}{l}\text { VAT } \\
\text { Fuel duties } \\
\text { Stamp duties } \\
\text { Tobacco duties } \\
\text { Spirits duties } \\
\text { Wine duties } \\
\text { Beer and cider duties } \\
\text { Betting and gambling duties } \\
\text { Air passenger duty } \\
\text { Customs duties and levies } \\
\text { Insurance premium tax } \\
\text { Vehicle Excise Duties }\end{array}$ & VAT and other indirect taxes \\
\hline $\begin{array}{l}\text { Corporation tax } \\
\text { Corporation tax credits } \\
\text { Capital Gains Tax } \\
\text { Petroleum revenue } \\
\text { PC corporation tax payments }\end{array}$ & Company and capital taxes \\
\hline Inheritance tax & Inheritance tax \\
\hline Council Tax & Council Tax \\
\hline Business rates & Business rates \\
\hline $\begin{array}{l}\text { Gross operating surplus and rents } \\
\text { Interests and dividends }\end{array}$ & Gross operating surplus and rents \\
\hline $\begin{array}{l}\text { Landfill Tax } \\
\text { Climate change levy } \\
\text { Aggregates levy } \\
\text { Other taxes and royalties } \\
\text { Adjustments } \\
\text { Other receipts }\end{array}$ & Other \\
\hline
\end{tabular}

Note. The Table reports the list of receipts from Table C4 of the Public Sector Finances Databank and the category in which they have been grouped.

(C) 2014 Royal Economic Society. 
THE FISCAL EFFECTS OF IMMIGRATION

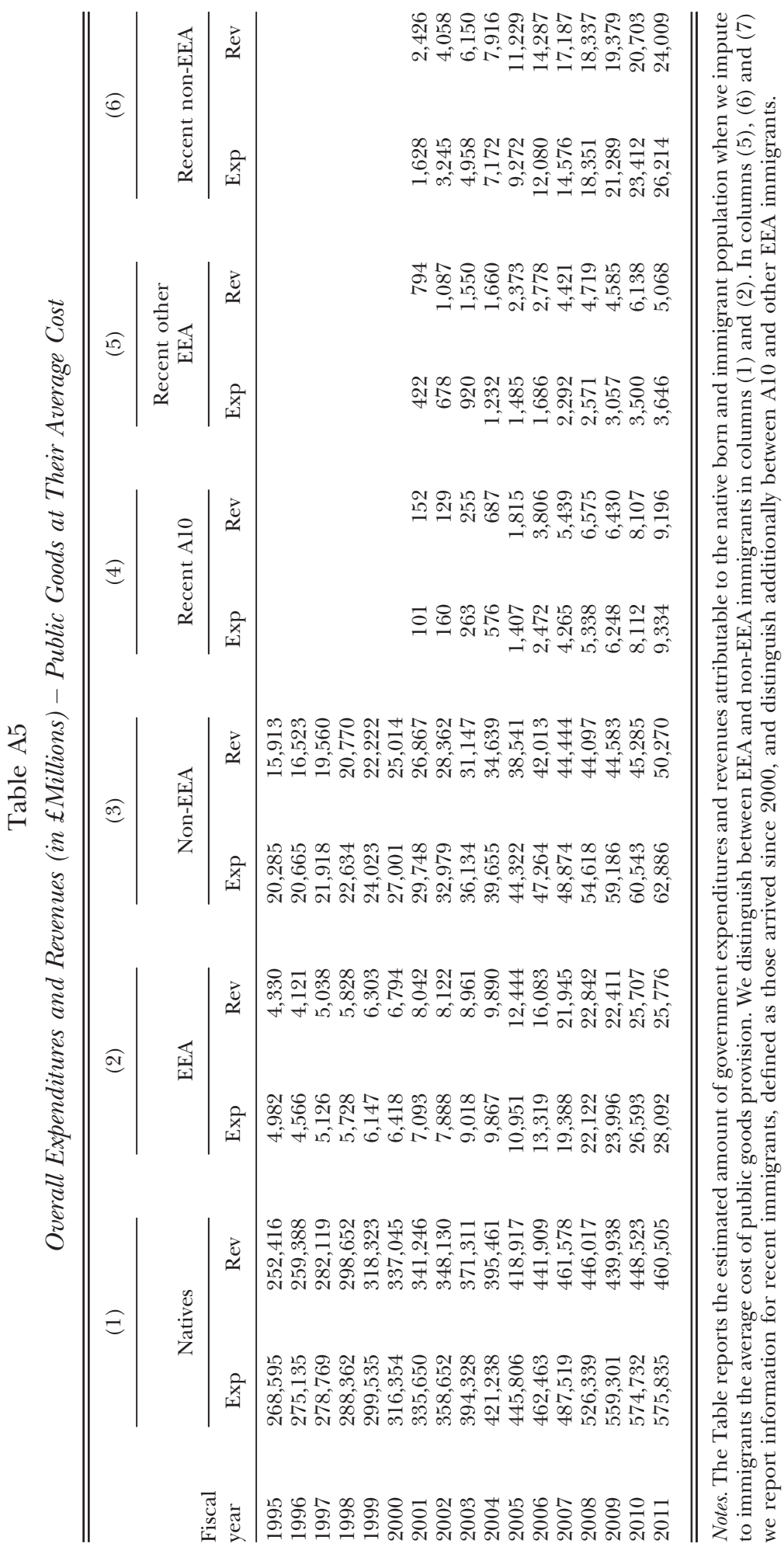

(C) 2014 Royal Economic Society. 


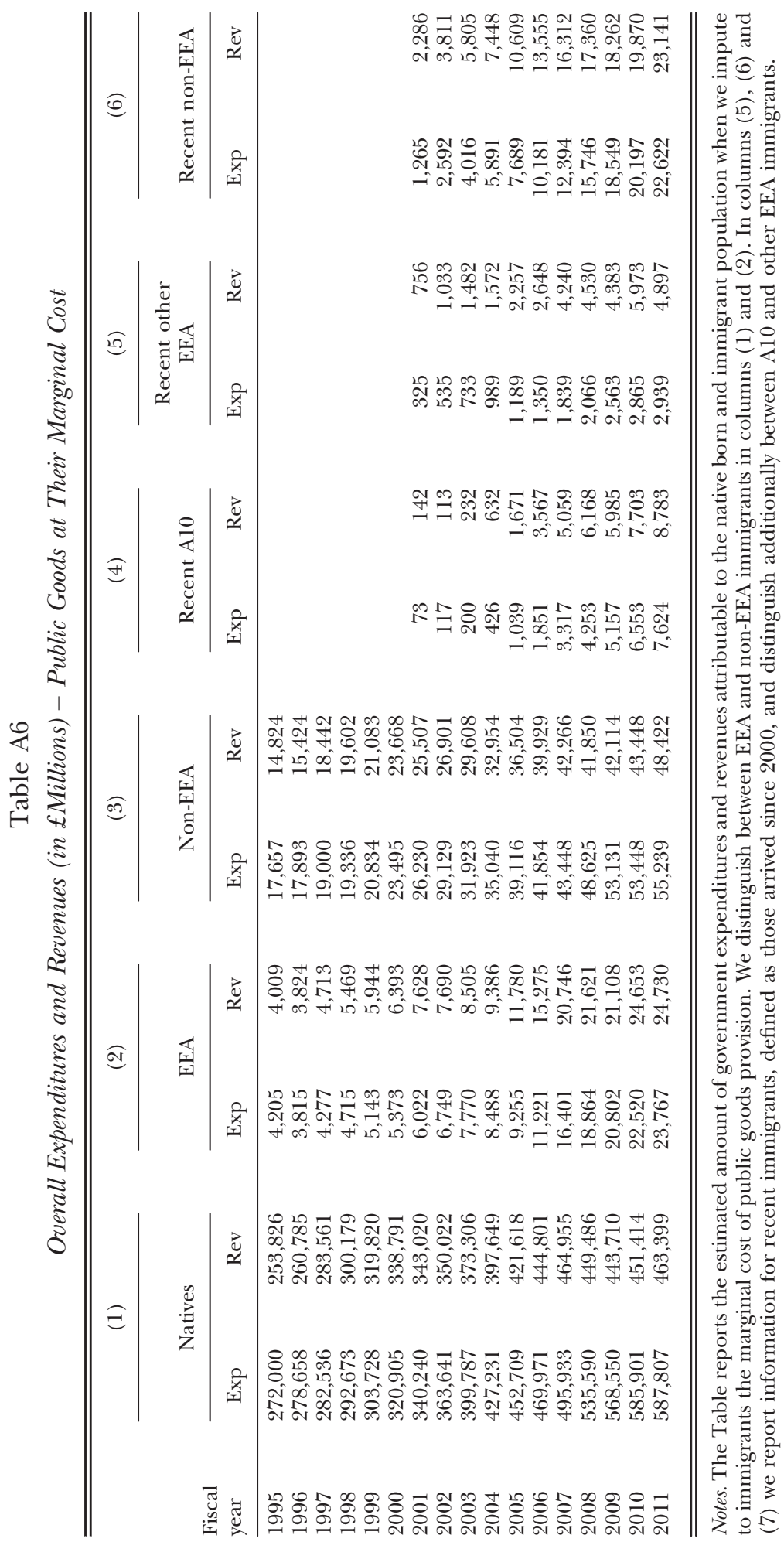


Table A7

Robustness Checks

\begin{tabular}{|c|c|c|c|}
\hline & Natives & EEA & Non-EE \\
\hline & \multicolumn{3}{|c|}{$\begin{array}{l}\text { Overall net fiscal contributions } \\
\text { (£million, } 2011 \text { equivalent })\end{array}$} \\
\hline \multicolumn{4}{|l|}{ Panel (a): 1995-2011 } \\
\hline (a) Imputing self-employed income & $-594,679$ & 2,822 & $-113,173$ \\
\hline (b) Imputing self-employed and pension income & $-591,554$ & 2,961 & $-116,437$ \\
\hline (c) Immigrants' consumption is $80 \%$ than natives' & $-545,882$ & $-8,248$ & $-150,89$ \\
\hline (d) Assigning capital taxation to long-term residents & $-556,621$ & $-5,912$ & $-142,49$ \\
\hline (e) Accounting for number of children in family benefits & $-572,834$ & 6,103 & $-138,29$ \\
\hline $\begin{array}{l}\text { (f) Marginal cost (MC) scenario + imputing } \\
\text { self-employed income }\end{array}$ & $-676,766$ & 26,567 & $-54,83$ \\
\hline $\begin{array}{l}\text { (g) MC scenario + Imputing self-employed and } \\
\text { pension income }\end{array}$ & $-673,641$ & 26,706 & $-58,09$ \\
\hline $\begin{array}{l}\text { (h) MC scenario + Immigrants' consumption is } 80 \% \\
\text { than natives' }\end{array}$ & $-627,970$ & 15,497 & $-92,556$ \\
\hline $\begin{array}{l}\text { (i) MC scenario + assigning capital taxation to long } \\
\text { term residents }\end{array}$ & $-638,708$ & 17,833 & $-84,15$ \\
\hline $\begin{array}{l}\text { (j) MC scenario }+ \text { accounting for number of children in } \\
\text { family benefits }\end{array}$ & $-654,921$ & 29,848 & $-79,956$ \\
\hline
\end{tabular}

Natives $\frac{\text { Recent A10 }}{\begin{array}{c}\text { Overall net fiscal contributions } \\ \text { (£million, 2011 equivalent) }\end{array}} \stackrel{\begin{array}{c}\text { Recent other } \\ \text { EEA }\end{array}}{\begin{array}{c}\text { Recent } \\ \text { non-EEA }\end{array}}$

Panel (b): 2001-11

(a) Imputing self-employed income

$\begin{array}{lll}4,397 & 11,758 & -7,423\end{array}$

(b) Imputing self-employed and pension income $\quad-609,057$

\section{3,553}

(c) Immigrants' consumption is $80 \%$ than natives'

(e) Accounting for number of children in

family benefits

(f) Marginal cost (MC) scenario + imputing

self-employed income

(g) MC scenario + Imputing self-employed and pension income

(h) MC scenario + Immigrants' consumption is $80 \%$ than natives'

(i) MC scenario + assigning capital taxation to long-term residents

(j) MC scenario + accounting for number of children in family benefits
11,997

$-581,640$

$-588,722$

$-602,383$

$-674,306$

2,071

13,369

$66 \quad 12,542$

$5,296 \quad 15,363$

$-8,511$

$-3,143$

$-9,915$

2,314

$9,930 \quad 14,739$

7,872

$\begin{array}{lll}-671,637 & 9,087 & 14,978\end{array}$

6,783

$\begin{array}{lll}-644,220 & 7,604 & 16,351\end{array}$

12,152

$-651,302$

5,599

15,523

5,380

$\begin{array}{lll}-664,963 & 10,829 & 18,344\end{array}$

17,608

Notes Panel (a) reports, for natives, EEA and non-EEA immigrants, cumulated over fiscal years 1995-2011 their overall net fiscal contribution, expressed in $£ 2011$ equivalent, when we allocate to immigrants the average cost of public goods (a-e) and (a) impute income of the self-employed, based on their sector of activity, (b) impute additionally state pension income to pension recipients, (c) assume that immigrants consume $80 \%$ than comparable natives, (d) assign all revenues from company and capital taxes to natives and immigrants in the UK for $>10$ years, (e) account for number of dependent children in apportioning social expenditures on family and children. In rows $(f-j)$, we report results under the same assumptions but we allocate immigrants the marginal cost of public goods. Panel $(b)$ reports the same estimates for natives and recent immigrants (arrived since 2000), where we distinguish between A10, other EEA and non-EEA, and cumulated over fiscal years 2001-11. 
University College London

University of Milan; University College London and Centro Studi Luca d'Agliano (LdA)

Additional Supporting Information may be found in the online version of this article:

Appendix B. Educational Savings

Data S1.

\section{References}

Altonji, J.G. and Card, D. (1991), 'The effects of immigration on the labor market outcomes of less-skilled natives', in (J.M. Abowd and R.B. Freeman, eds.), Immigration, Trade and Labor, pp. 201-34, Chicago, IL: University of Chicago Press.

Arulampalam, W., Devereux, M.P. and Maffini, G. (2012), 'The direct incidence of corporate income tax on wages', European Economic Review, vol. 56(6), pp. 1038-54.

Auerbach, A.J. (2006), 'Who bears the corporate tax? A review of what we know', in (J.M. Poterba, ed.), Tax Policy and the Economy, vol. 20, pp. 1-40, Cambridge, MA: MIT Press.

Barrett, A. and McCarthy, Y. (2008), 'Immigrants and welfare programmes: exploring the interactions between immigrant characteristics, immigrant welfare dependence and welfare policy', Oxford Review of Economic Policy, vol. 24(3), pp. 542-59.

Boeri, T. (2010), 'Immigration to the land of redistribution', Economica, vol. 77(308), pp. 651-87.

Boldrin, M. and Montes, A. (2005). 'The intergenerational state education and pensions', Review of Economic Studies, vol. 72(3), pp. 651-64.

Borjas, G.J. (2003). 'The labor demand curve is downward sloping: reexamining the impact of immigration on the labor market', Quarterly Journal of Economics, vol. 118(4), pp. 1335-74.

Bozio, A., Crawford, R. and Tetlow, G. (2010), 'The history of state pensions in the UK: 1948 to 2010', IFS Briefing Note No. 105.

Bratsberg, B., Raaum, O. and Roed, K. (2014), 'Immigrants, labor market performance, and social insurance', EconOMIC Journal, vol. ???(???), pp. ???-???.

Card, D. (1990). 'The impact of the Mariel Boatlift on the Miami labor market', Industrial and Labor Relations Review, vol. 43(2), pp. 245-57.

Card, D. (2001). 'Immigrant inflows, native outflows, and the local labor market impacts of higher immigration', Journal of Labor Economics, vol. 19(1), pp. 22-64.

Carroll, C.D., Rhee, B.-K. and Rhee, C.-Y. (1999). 'Does cultural origin affect saving behavior? Evidence from immigrants', Economic Development and Cultural Change, vol. 48(1), pp. 33-50.

Chiswick, B.R. (1978). 'The effect of Americanization on the earnings of foreign-born men', Journal of Political Economy, vol. 86(5), pp. 897-921.

Drinkwater, S. and Robinson, C. (2013). 'Welfare participation by immigrants in the UK', International Journal of Manpower, vol. 34(2), pp. 100-12.

Dustmann, C. (1997), 'Return migration, uncertainty and precautionary savings', Journal of Development Economics, vol. 52(2), pp. 295-316.

Dustmann, C. and Fabbri, F. (2005). 'Immigrants in the British labour market', Fiscal Studies, vol. 26(4), pp. $423-70$.

Dustmann, C., Fabbri, F. and Preston, I. (2005). 'The impact of immigration on the British labour market', ECONOMIC JOURNAL, vol. 115(507), pp. F324-41.

Dustmann, C., Fasani, F. and Speciale, B. (2014), 'Illegal migration and consumption behaviour of immigrant households', unpublished manuscript, University College, London.

Dustmann, C. and Frattini, T. (2013), 'Immigration: the European experience', in (D. Card, S. Raphael, S., eds.), Immigration, Poverty and Socioeconomic Inequality, pp. 423-56, New York: Russell Sage Foundation

Dustmann, C., Frattini, T. and Halls, C. (2010). 'Assessing the fiscal costs and benefits of A8 migration to the UK', Fiscal Studies, vol. 31(1), pp. 1-41.

Dustmann, C., Frattini, T. and Preston, I. (2013). 'The effect of immigration along the distribution of wages', Review of Economic Studies, vol. 80(1), pp. 145-73.

Dustmann, C., Frattini, T. and Rosso, A. (2015), 'The effect of emigration from Poland on Polish wages', Scandinavian Journal of Economics (forthcoming). 
Dustmann, C. and Gorlach, S.J. (2014), 'Selective outmigration and the estimation of immigrants' earnings profiles', in (B.R. Chiswick and P.W. Miller, eds.), Handbook of the Economics of International Migration, Amsterdam: Elsevier (forthcoming).

Dustmann, C., Machin, S. and Schoenberg, U. (2011). 'Ethnicity and educational achievement in compulsory schooling', Economic Journal, vol. 120 (546), pp. F272-97.

Dustmann, C. and Preston, I. (2007), 'Racial and economic factors in attitudes to immigration', B.E. Journal of Economic Analysis and Policy, vol. 7(1), pp. 1-41. (Advances), Article 62.

Dustmann, C. and Theodoropoulos, N. (2010). 'Ethnic minority ommigrants and their children in Britain', Oxford Economic Papers, vol. 62(2), pp. 209-33.

Dustmann, C. and Weiss, Y. (2007). 'Return migration: theory and empirical evidence for the UK', British Journal of Industrial Relations, vol. 45(2), pp. 236-56.

Gott, C. and Johnston, K. (2002), 'The migrant population in the UK: fiscal effects', Home Office Research, Development and Statistics Directorate Occasional Paper No.77, London.

Gravelle, J.C. (2011), 'Corporate tax incidence: a review of empirical estimates and analysis', CBO Working Paper No. 2011-01, Congressional Budget Office, Washington, DC.

Gravelle, J.C. (2013). 'Corporate tax incidence: review of general equilibrium estimates and analysis', National Tax Journal, vol. 66(1), pp. 185-214.

Harberger, A.C. (1962). 'The incidence of the corporate income tax', Journal of Political Economy, vol. 70(3), pp. $215-40$.

Harberger, A.C. (2008). 'Corporate tax incidence: reflections on what is known, unknown, and unknowable', in (J.W. Diamond and G.R. Zodrow, eds.), Fundamental Tax Reform: Issues, Choices, and Implications, pp. 283-308. Cambridge, MA: MIT Press.

Liebig, T. and Mo, J. (2013), 'The fiscal impact of immigration in OECD countries', chapter 3, in (OECD, ed.), International Migration Outlook 2013, pp. 125-89, Paris: OECD Publishing.

Manacorda, M., Manning, A. and Wadsworth, J. (2012). 'The impact of immigration on the structure of wages: theory and evidence from Britain', Journal of the European Economic Association, vol. 10(1), pp. 12051.

Ottaviano, G.I.P. and Peri, G. (2012). 'Rethinking the effect of immigration on wages', Journal of the European Economic Association, vol. 10(1), pp. 152-97.

Piracha, M. and Zhu, Y. (2012). 'Precautionary savings by natives and immigrants in Germany', Applied Economics, vol. 44(21), pp. 2767-76.

Preston, I. (2014), 'The effect of immigration on public finances', EconOMIC JOURnAL, vol. ???(???), pp. ???-???.

Rangel, A. (2003). 'Forward and backward intergenerational goods: why is social security good for the environment?', American Economic Review, vol. 93(3), pp. 813-34.

Rowthorn, R. (2008). 'The fiscal impact of immigration on the advanced economies', Oxford Review of Economic Policy, vol. 24(3), pp. 560-80.

Rowthorn, R. (2014), 'A note on Dustmann and Frattini's "Estimates of the fiscal impact of UK immigration", mimeo, www.civitas.org.uk/pdf/rowthorndustmannfrattini.pdf (last accessed: 23 August 2014).

Sriskandarajah, D., Cooley, L. and Reed, H. (2005). 'Paying their way: the fiscal contribution of immigrants in the UK', research report, Institute for Public Policy Research, London.

Wadsworth, J. (2013). 'Musn't grumble: immigration, health and health service use in the UK and Germany', Fiscal Studies, vol. 34(1), pp. 55-82. 